GREENING EDUCATION: CHALLENGES AND PROSPECTS OF IMPLEMENTING GREEN ROOFS ACROSS TORONTO PUBLIC SCHOOLS

by

Pegah Abhari

BA (Honours), York University, 2016

\author{
A Major Research Paper \\ presented to Ryerson University \\ in partial fulfillment of the requirements for the degree of \\ Master of Planning \\ In \\ Urban Development
}

Toronto, Ontario, Canada, 2018

(C) Pegah Abhari, 2018 


\section{Author's Declaration for Electronic Submission of a MRP}

I hereby declare that I am the sole author of this MRP. This is a true copy of the MRP, including any required final revisions.

I authorize Ryerson University to lend this MRP to other institutions or individuals for the purpose of scholarly research.

I further authorize Ryerson University to reproduce this MRP by photocopying or by other means, in total or in part, at the request of other institutions or individuals for the purpose of scholarly research.

I understand that my MRP may be made electronically available to the public. 


\title{
GREENING EDUCATION: CHALLENGES AND PROSPECTS OF IMPLEMENTING GREEN ROOFS ACROSS TORONTO PUBLIC SCHOOLS
}

\author{
(C) Pegah Abhari, 2018 \\ Master of Planning \\ in \\ Urban Development \\ Ryerson University
}

\begin{abstract}
Green roofs have been recognized as an important climate change adaptation and mitigation tool across North American Cities. As such, the City of Toronto sought regulation and incentives to encourage the adoption of green roofs across new developments and building additions, becoming the first North American City to establish mandatory legislation. While the policy has been mainly successful, Toronto School Boards have struggled to adhere to regulations. This paper seeks to identify the barriers that Toronto School Boards face in green roof implementation by undertaking an analysis of available data, resources, and literature. It also assesses the role of federal, provincial and municipal governments in alleviating barriers, providing recommendations on how they may be addressed. The aim of such research is to guide other Ontario municipalities who may look to Toronto when developing similar legislation, as the province moves to expand this permission to all municipalities.
\end{abstract}

Key words: green infrastructure; green roofs; Toronto School Boards; green education 


\section{Acknowledgments}

Studying urban planning at Ryerson over the past two years has been a great opportunity and eye-opening experience. It has been a pleasure to learn about the intricate process of citybuilding from such wonderful faculty, who have challenged my own perceptions of what urban planning can be. I take with me the lessons I have learnt here to apply myself to this increasingly changing, dynamic, and interdisciplinary field. I hope that my future as a practitioner truly reflects the values that I have developed here.

Firstly, I want to thank my supervisor, Dr. Chris De Sousa for his continuous support and motivations. Even when the process seemed overwhelming, he never veered from directing me in the right path. Thank you to my second reader, Shayna Stott, for her insights and feedback. Most importantly, thanks for leading me towards environmental policy regulation and sharing your expertise on such an important topic.

To my friends, classmates, and future practitioners, I thank you for challenging me these past two years. It has been a pleasure getting to know you all, and I'm thankful for the lifelong friendships that have formed throughout this experience. 


\section{Dedication}

To my parents, sister and friends, I can't begin to thank you for your understanding and support throughout this process. Mom and dad, thanks for the many sacrifices you have made to allow my pursuit of this degree to be possible in the first place. I cannot begin to thank you enough for all that you have done and continue to do.

To Luisa and Abilio, thanks for opening your home to me for the past two years, allowing me the time necessary to dedicate to my studies instead of dreadful commutes.

To my partner, Jonathan, I love you and I am so grateful for your continuous support. Thanks for sticking by me through the seven long years of continuous studying and stress.

Finally, to Bella, I regret being so occupied these last two years and not spending more time with you when I had the chance. I hope you're looking down on me proudly. 


\section{Abbreviations}

UHI - Urban Heat Island

UGI - Urban Green Infrastructure

COTA - City of Toronto Act, 2006

CSO - Combined Sewer Overflow

TDSB - Toronto District School Board

TCDSB - Toronto Catholic District School Board

TGRCS - Toronto Green Roof Construction Standard

FCM - Federation of Canadian Municipalities'

GMF - Green Municipal Fund

SRI - Solar Reflectance Index 


\section{TABLE OF CONTENTS}

Author's Declaration for Electronic Submission of a MRP ii

Acknowledgments $\quad$ iv

Dedication v v

Abbreviations $\quad$ vi

List of Tables $\quad x$

List of Figures $\quad$ xi

$\begin{array}{ll}\text { INTRODUCTION } & 1\end{array}$

Statement of PROBlem

RESEARCH OBJECTIVES AND QUESTIONS

PAPER STRUCTURE

SECTION 1: BACKGROUND

$\begin{array}{ll}\text { 1.0 URBANIZATION AND THE CITY OF TORONTO } & 7\end{array}$

2.0 GREEN ROOF TYPOLOGIES $\quad 9$

2.1 GREen ROOF SYSTEMS

2.1.1 EXTENSIVE GREEN ROOFS

2.1.2 INTENSIVE GREEN ROOFS 12

2.1.3 SEMI-INTENSIVE GREEN ROOFS 13

1.2 COOL ROOFS 14

$\begin{array}{ll}\text { 3.0 GREEN ROOF BENEFITS } & 15\end{array}$

3.1 ENVIRONMENTAL BENEFITS

3.2 SOCIAL BENEFITS 16

3.3 ECONOMIC BENEFITS 18

\begin{tabular}{ll} 
4.0 POLICY DEVELOPMENT & 21 \\
\hline
\end{tabular}

4.1 City of TOROnto's Green Roof Strategy

4.1.1 GREEN ROOF PILOT INCENTIVE PROGRAM 22

4.1.2 USE OF DEVELOPMENT PROCESS TO ENCOURAGE GREEN ROOFS 23

4.1.3 GREEN ROOF INSTALLATIONS ON CITY OWNED BUILDINGS 23

4.1.4 PUBLIC EDUCATION AND PROMOTION

4.2 The Role of TORONTO SCHOOl BoARds in POLICY DEVElopment 
5.1.1 ESTABLISHING AUTHORITY FOR REGULATION 26

5.1.2 ESTABLISHING CONSTRUCTION STANDARDS

5.1.3 ESTABLISHING REGULATION 28

5.1.4 CASH-IN-LIEU PROCESS

5.1.5 EXEMPTIONS 31

5.1.6 ESTABLISHING INCENTIVES

SECTION 2: ANALYSIS

\begin{tabular}{ll} 
6.0 QUANTITATIVE ANALYSIS & 34 \\
\hline
\end{tabular}

6.1 Methodology 34

6.2 DATA ANALYSIS

6.2.1 ANALYSIS OF SITE PLAN APPLICATIONS FOR TORONTO PUBLIC SCHOOL BOARDS

6.2.2 ANALYSIS OF GREEN ROOF PERMIT APPLICATIONS

6.2.3 ANALYSIS OF CASH-IN-LIEU DOCUMENTS

6.3 LIMITATIONS $\quad 41$

$\begin{array}{ll}\text { 7.0 BARRIERS TO GREEN ROOF IMPLEMENTATION } & 43\end{array}$

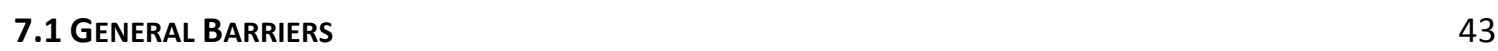

7.1.1 LACK OF INFORMATION, AWARENESS AND UNCERTAINTY

7.1.2 COST OF INSTALLATION AND MAINTENANCE

7.1.3 LACK OF RESEARCH, STANDARDS AND TECHNICAL EXPERTISE

7.1.4 STRUCTURAL CAPACITY FOR RETROFITS

7.2 BARRIERS FACED BY TORONTO SCHOOL BOARDS

7.2.1 MAINTENANCE MANAGEMENT AND COSTS

7.2.2 STRUCTURAL CAPACITY FOR RETROFITS

7.2.3 LACK OF AWARENESS OF GREEN ROOF BENEFITS

7.2.4 LACK OF TECHNICAL GUIDANCE

7.2.5 FUNDING CONCERNS

7.2.6 SAFTEY CONCERNS

7.2.7 ADMINISTRATIVE BURDENS 56

7.2.8 PARTNERSHIP OPPORTUNITIES 


\section{SECTION 3: MOVING FORWARD}

8.0 INTER-GOVERNMENTAL COLLABORATION

8.1 Federal Policies ANd Funding SoURCES

8.2 Provincial Policies and Funding SOURCES

10.2 Provincial Action

10.3 MUNICIPAL ACTION

10.4 TORONTO PUBLIC SCHOOL BOARDS 


\section{List of Tables}

Table 1: Functions and Components of a Typical Green Roof System 10

Table 2: Features of an Extensive Green Roof System 12

Table 3: Features of an Intensive Green Roof System 13

Table 4: Estimated City-wide Potential Value of Green Roofs in Toronto 19

Table 5: Change is in the Air: Toronto's Climate Change and Clean Air Action Plan 27

Table 6: City of Toronto Green Roof Requirement 30 


\section{List of Figures}

Figure 1: Green Roof Components $\quad 9$

Figure 2: Construction of Green Roof or Alternative Roof Surfaces (COTA Excerpt) 27

Figure 3: Toronto Public School Site Plan Applications Requiring Green Roof Installations 36

Figure 4: Toronto Public School Site Plan Applications Requiring Green Roof Installations by

Building Type

Figure 5: Breakdown of Green roof coverage of permit applications by Toronto Public Schools 


\section{INTRODUCTION}

\section{STATEMENT OF PROBLEM}

As climate change continues to challenge city resilience, it is important to focus on creating cities that aim to proactively withstand these challenges. City builders must plan for growth in a way that builds resiliency and economic growth that is sensitive to sustainability. Planning for Green Infrastructure has been an expanding field throughout the last decade, and its importance as a measure for fostering sustainable growth has grown exponentially. Urban Green Infrastructure (UGI) provides a network of planned and unplanned green spaces, within both the private and public realms, which aim to offset the negative externalities of traditional 'grey infrastructure' growth (Norton, et. al., 2015). This definition encompasses engineered solutions such as green roofs (Binstock, 2011), which have been proven to be an important component of adaptation and mitigation strategies, while creating immense environmental, economic and social benefits.

Realizing these benefits, the City of Toronto established the Green-roof By-law in 2009, mandating strict technological standards and providing direct financial incentives for voluntary green roof development through the eco-roof incentive program (Forbes, 2010). Following bylaw implementation, publicly funded school boards were amongst the first to attempt exemption from legislation, as the cost of implementation and maintenance was ostensibly too great of a barrier without financial supports (Roberts, 2012). In response, the City expanded the eco-roof incentive program to become applicable for schools seeking voluntary or mandated construction of green roofs. Although the policy has been heralded as a success in producing 
green roofs on most commercial, industrial and institutional developments and building additions, school boards are still struggling to adhere to the by-law. As it stands, the City of Toronto is the only municipality in Ontario to have provincial permission to mandate the construction of green roofs, due to provisions outlined in the City of Toronto Act, 2006. However, recent changes to the Municipal Act allow all municipalities to pass similar by-laws. Conversely, the provincial building code lacks standards for green roofs, preventing this from coming into fruition (Ministry of Municipal Affairs, 2017a). The province is now looking to amend the Ontario Building Code for 2019, and has reported the possibility of including standards for environmentally friendly roof construction, enabling other municipalities to implement such regulation (Ministry of Municipal Affairs, 2017a). With these recent changes many municipalities could soon choose to require green roofs on institutions such as schools.

The Challenges that Toronto school boards face in implementing green roofs can help to inform other municipality's who may choose to adopt green roof policies or legislation. There are currently 4,900 publicly funded elementary and secondary schools in Ontario, representing approximately 280 million square feet of space across the province (Ministry of Education, 2017). Unless solutions could be identified, these spaces in addition to newly built schools might never incorporate green roof technologies, resulting in a loss of opportunity to attain associated environmental, economic, and social benefits.

To date, very little research has been conducted to examine the barriers that Toronto school boards face in green roof implementation. The only available resource is the Eco-Roof Incentive Program Review Final Report completed in 2016 by Lura Consulting and the Cardinal 
Group for the City of Toronto (Baynton \& D'Souza, 2016). This report conducted interviews with the Toronto District School Board, Toronto Catholic District School board and the Toronto French Catholic School Board as part of their investigation; its primary objective was to identify barriers to the participation in the City's Eco-roof Incentive program. This paper will seek to examine the challenges and barriers to green roof implementation on school buildings within the City of Toronto and explore recommendations to address such barriers.

\section{RESEARCH OBJECTIVES AND QUESTIONS}

The primary objective of this report is to identify the obstacles that prevent the incorporation of green roofs in the development of new school buildings and school building additions within the City of Toronto. It will also focus on future directions to alleviate the pressure school boards face in adhering to the City's Green Roof By-law at the municipal level as well the provincial and federal levels within the context of green infrastructure investment. Additionally, recommendations will be made in an effort to direct policy development in other municipalities within Ontario, should others be looking to implement such regulation. The research questions that will guide this report are:

I. What types of green roofs exist and what benefits do green roofs produce?

II. What barriers do Toronto schools face in implementing green roofs? With these barriers in mind, is it currently feasible or beneficial to establish green roofs on school buildings?

III. How can the experience of Toronto Public Schools inform policy decisions for other Ontario Municipalities? 


\section{PAPER STRUCTURE}

\section{SECTION 1: BACKGROUND}

CHAPTER 1: URBANIZATION AND GROWTH - Following this introductory chapter, Chapter one will discuss the rate of urbanization in the City of Toronto, as well as the present and forecasted impacts of urbanization and climate change within the City.

CHAPTER 2: GREEN ROOF TYPOLOGIES - Chapter two will explore green roof definitions and available green roof typologies in the Canadian market.

CHAPTER 3: GREEN ROOF BENEFITS - Chapter three will investigate the environmental, social and economic benefits that green roofs produce.

CHAPTER 4: GREEN ROOF POLICY; POLICY DEVELOPMENT - Chapter four will look at the motivations underlying widespread green roof implementation and tracks the process of green roof policy development within the City of Toronto. This section will also explore the role of Toronto Public School Boards in the policy development stage.

CHAPTER 5: GREEN ROOF POLICY; CURRENT CONTEXT - Chapter five examines the state of current green roof policy and regulation within the City of Toronto, and tracks policy improvements throughout the years. In particular, it will look at the issues raised by school boards regarding policy, and seek actions taken by stakeholders to address such issues.

\section{SECTION 2: ANALYSIS}

CHAPTER 6: QUANTITATIVE ANALYSIS - Chapter six will undertake an analysis of site plan applications for Toronto Public school boards from January 2010 to October 2017 to determine the rate of School Board applications that were captured by the Green Roof By-law. Furthermore, green roof permit applications retrieved form open data will be analyzed to 
determine the amount of School Board applications that provided a full, partial or no green roof within developments. Finally, this section will evaluate cash-in-lieu documentation submitted to the City of Toronto pertaining to School Board applications opting out of providing a full green roof as required in order to determine the causes underlying their decision to provide cash-inlieu.

CHAPTER 7: BARRIERS TO GREEN ROOF IMPLEMENTATION - Chapter seven will investigate general barriers to green roof implementation and green infrastructure investments as discussed in literature. Furthermore, information extracted from interviews with school board representatives in the 2016 review of the Eco-roof Incentive Program (conducted by Lura Consulting Inc.) will be analyzed to assess the nature of specific barriers that School Boards face in green roof implementation.

\section{SECTION 3: MOVING FORWARD}

CHAPTER 8: INTER-GOVERNMENTAL COLLABORATION - Chapter eight will explore the role of the federal, provincial and municipal governments in addressing barriers to green roof implementation. This is done through an assessment of relevant policies at various government levels, complemented by literature on the role of government in climate change adaptation.

CHAPTER 9: DISCUSSION - This chapter considers the barriers to green roof implementation found within the study and discusses potential next steps in addressing these barriers to aid School Boards in adopting green roofs within new and retrofit developments.

CHAPTER 10: RECOMMENDATIONS - This Chapter puts forth suggested actions for the federal, provincial, municipal governments, as well as School Boards to improve uptake of green roofs 
across Toronto Public School developments and additions. In addition, this section directs future research in areas deemed to lack critical data and information necessary to propel action by School Boards.

CHAPTER 11: CONCLUSION - Finally, the last chapter reflects on information found throughout the study and discusses the implications, barriers and potential improvements for Toronto School Boards in green roof implementation and what it could mean for other Ontario Municipalities looking to follow suit. 


\section{SECTION 1: BACKGROUND}

\subsection{URBANIZATION AND THE CITY OF TORONTO}

Growth in a number of North American cities is occurring rapidly, and the City of Toronto is no exception. Between 2011 and 2016, Toronto was among the three Canadian cities that saw significant population growth of over 100,000 people, with an increase of 4.5 per cent to a total population of $2,731,571$ people with this trend expected to continue (City of Toronto, 2017a). By 2041, the Growth Plan for the Greater Golden Horseshoe forecasts 3.4 million people and 1.72 million jobs in the City of Toronto (Ministry of Municipal Affairs, 2017b). As Canada's most populous city, Toronto has become the economic epicenter. The City is driving development and growth, experiencing surges in both residential and non-residential development (City of Toronto, 2017b). In a four-year span from 2012 to 2016, 363,859 residential units and 9.53 million meters square of non-residential gross floor area (GFA) were proposed in the City of Toronto (ibid). In 2016 alone, over \$7 billion dollars worth of building permits were sought (City of Toronto, n.d.[b]). The Growth Plan for the Greater Golden Horseshoe directs municipalities to efficiently use existing land and infrastructure, by prioritizing intensification and higher densities in urban growth centers (Ministry of Municipal Affairs, 2017b). Toronto has conformed to this direction, as $39 \%$ of units proposed and $41 \%$ of non-residential GFA proposed were located in the Downtown \& Central Waterfront Centre, 36\% of residential units were proposed in the Yonge-Eglinton Centre and $44 \%$ of proposed nonresidential GFA was proposed in North York Centre (City of Toronto, 2017b). 
Urbanization in the City of Toronto has placed significant pressure on the City and the concentration of dense development has created a paradox. While it results in the preservation of land and resources, it also introduces a new set of environmental concerns. Rapid development has brought with it: an increase in the amount of impervious surfaces, changes to the natural hydrology of land, increased occurrences of flooding, habitat fragmentation, damages on ecosystem and ecological processes, increased urban heat island (UHI) effects resulting in rising urban temperatures and has enhanced the effects of climate change (Banting, et. al., 2005; Carter \& Fowler, 2008; Forbes, 2010; Lehmann, 2014; Mees \& Driessen, 2011). For decades investments in growth have been made through financing of traditional grey infrastructure; which has resulted in damage to water quality through cases such as combined sewer overflow's (CSO), declining air quality, increased greenhouse gas emissions, declining biodiversity and much more (Binstock, 2011; Foster, Lowe \& Winkelman, 2011). The consequences of our development choices are making it evident that now more than ever; there is a growing need for change. Green roofs have been proven to be part of the solution, as they are "structurally engineered and designed to combat urbanization" (Viijayaraghavan, 2016, 744). 


\subsection{GREEN ROOF TYPOLOGIES}

\subsection{GREEN ROOF SYSTEMS}

The City of Toronto considers green roofs as an extension of a roof that is a humanmade structure above grade, allowing the growth of vegetation designed, constructed and maintained in accordance with the Toronto Green Roof Construction Standard (City of Toronto, 2013a). Green roofs can be comprised of several layers (see figure 1): vegetation, growth substrate, filter fabric, drainage element, protection layer, root barrier, insulation layer, waterproofing membrane and the roof deck (Viijayaraghavan, 2016).

\section{Figure 1: Green Roof Components}

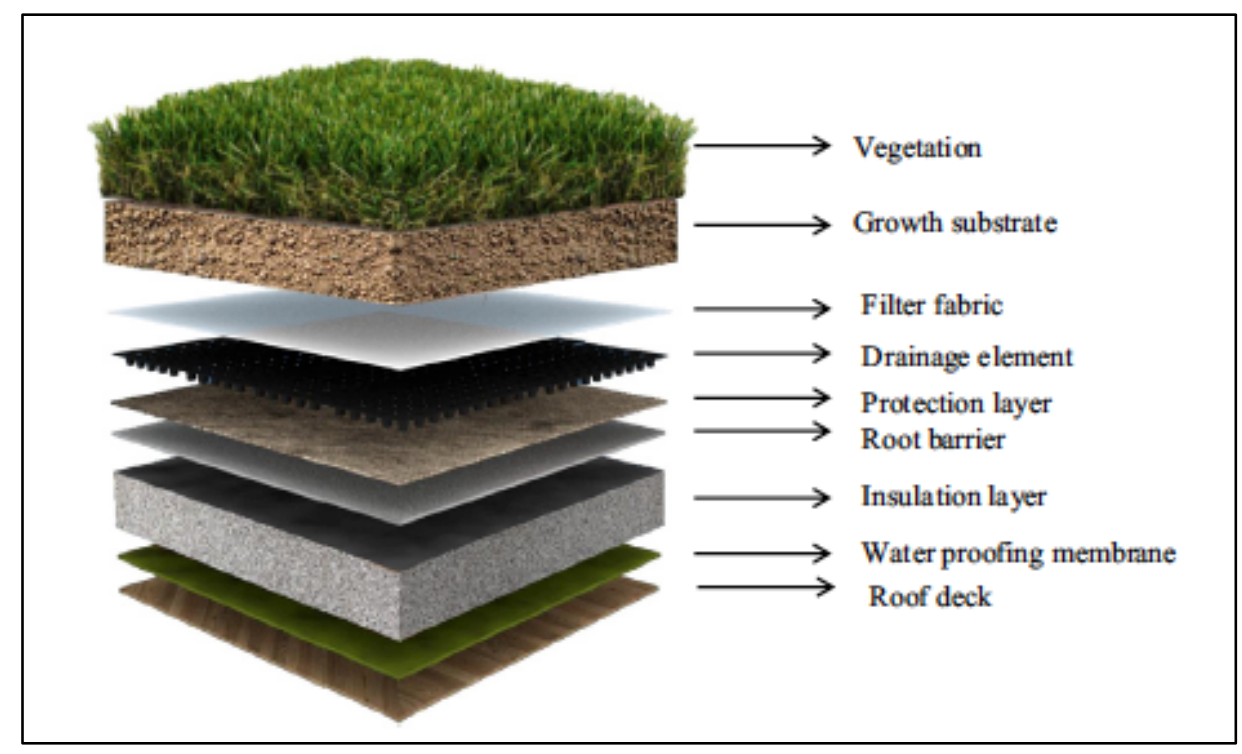

(Source: Viijayaraghavan, 2016, 744).

Depending on location and requirements (ibid), green roof manufacturers have various green roof systems that meet the needs of different climatic conditions and users (Bianchini \& Hewage, 2012). However, most green roof systems generally incorporate the vegetation, 
growth substrate/growing medium, water retention, filter drainage, root barrier and roofing assembly/deck components (ibid). Each component serves a different function, as described in table 1:

\begin{tabular}{|c|c|c|}
\hline Component & Function & Materials \\
\hline Root Barrier & $\begin{array}{l}\text { This is the first layer of a green roof } \\
\text { system and acts as a waterproof } \\
\text { membrane for the roof structure and } \\
\text { aims to protect the roof from } \\
\text { penetration of plant roots. }\end{array}$ & $\begin{array}{l}\text { Typically consists of a thin } \\
\text { layer of low density } \\
\text { polyethylene (LDPE) or } \\
\text { Polyethylene (PP) }\end{array}$ \\
\hline Drainage & $\begin{array}{l}\text { Effective drainage is required to } \\
\text { preserve structural capacity of the roof } \\
\text { and when excess water is present } \\
\text { causing additional weight placed on the } \\
\text { assembly, potential damage to the root } \\
\text { barrier, and water leaks. }\end{array}$ & $\begin{array}{l}\text { Varies depending on the } \\
\text { type of green roof } \\
\text { system, weather } \\
\text { conditions and roofing } \\
\text { assembly }\end{array}$ \\
\hline Filter Layer & $\begin{array}{l}\text { This layer prevents runoff particles and } \\
\text { materials from other layers from } \\
\text { blocking drainage below, maintaining } \\
\text { vegetation and medium integrity - it is } \\
\text { often considered as part of the drainage } \\
\text { layer as it is often bonded to it }\end{array}$ & $\begin{array}{l}\text { Typically materials are } \\
\text { made from polymeric } \\
\text { fibers or polyolefin }\end{array}$ \\
\hline Water Retention & $\begin{array}{l}\text { This layer retains and controls runoff } \\
\text { water in addition to maintaining } \\
\text { moisture in the growing medium layer. } \\
\text { The retention capacity depends on the } \\
\text { green roof system, types of vegetation, } \\
\text { roofing assembly, weather conditions } \\
\text { and soil saturation. }\end{array}$ & $\begin{array}{l}\text { Typically wool or } \\
\text { polymeric fiber mats - } \\
\text { thickness varies but depth } \\
\text { is usually from } 1-6.5 \mathrm{~cm} \text {; } \\
\text { layer can consist of } \\
\text { multiple mats }\end{array}$ \\
\hline Growing Medium & $\begin{array}{l}\text { Aids with water retention, thermal } \\
\text { performance, and biological functions } \\
\text { of plants. It also allots space for the } \\
\text { settlement of plant roots }\end{array}$ & $\begin{array}{l}\text { Content of the material } \\
\text { can vary; can use soil, add } \\
\text { clay or organic particles, } \\
\text { organic matter. Thickness } \\
\text { is related to vegetation } \\
\text { type }\end{array}$ \\
\hline Vegetation & $\begin{array}{l}\text { Aesthetic layer consisting of the } \\
\text { vegetation and plants; serving to } \\
\text { mitigate Urban Heat Island (UHI) effect, } \\
\text { improve air quality, replace displaced }\end{array}$ & $\begin{array}{l}\text { Vegetation varies } \\
\text { depending on climate and } \\
\text { green roof system }\end{array}$ \\
\hline
\end{tabular}


landscapes, enhance biodiversity, regulate stormwater runoff and other benefits

Source: adapted from Bianchini \& Hewage, 2012

The typical characteristics and properties of green roof layers can vary largely based on the type of green roof system installed. Every building offers particular opportunities and constraints that influence the optimal type or design of a green roof system, specific to the structure and its location (Peck, 2001). There are three types of green roof systems widely available and used within the industry: extensive green roofs, intensive green roof, and semi-intensive green roofs often referred to as a hybrid system.

\subsubsection{EXTENSIVE GREEN ROOFS}

Extensive green roofs are generally large and inaccessible and can be characterized as low weight systems, require a low capital cost, host a reduced diversity of plants and have minimal maintenance requirements (Peck \& Kuhn, n.d.; Peck, 2001). They typically only require a thin layer of soil or substrate layer, grow plants such as sedums and mosses, and are designed to be self-sustaining (Bianchini \& Hewage, 2012; Castleton, et. al., 2010). As a result, they tend to have less environmental benefits, such as a lower capacity for stormwater retention and milder effects on temperature control. These systems are preferred in cases of building retrofits, as they often do not challenge the structural integrity of the building (Castleton, et. al., 2010). Specific features are displayed in table 2 : 


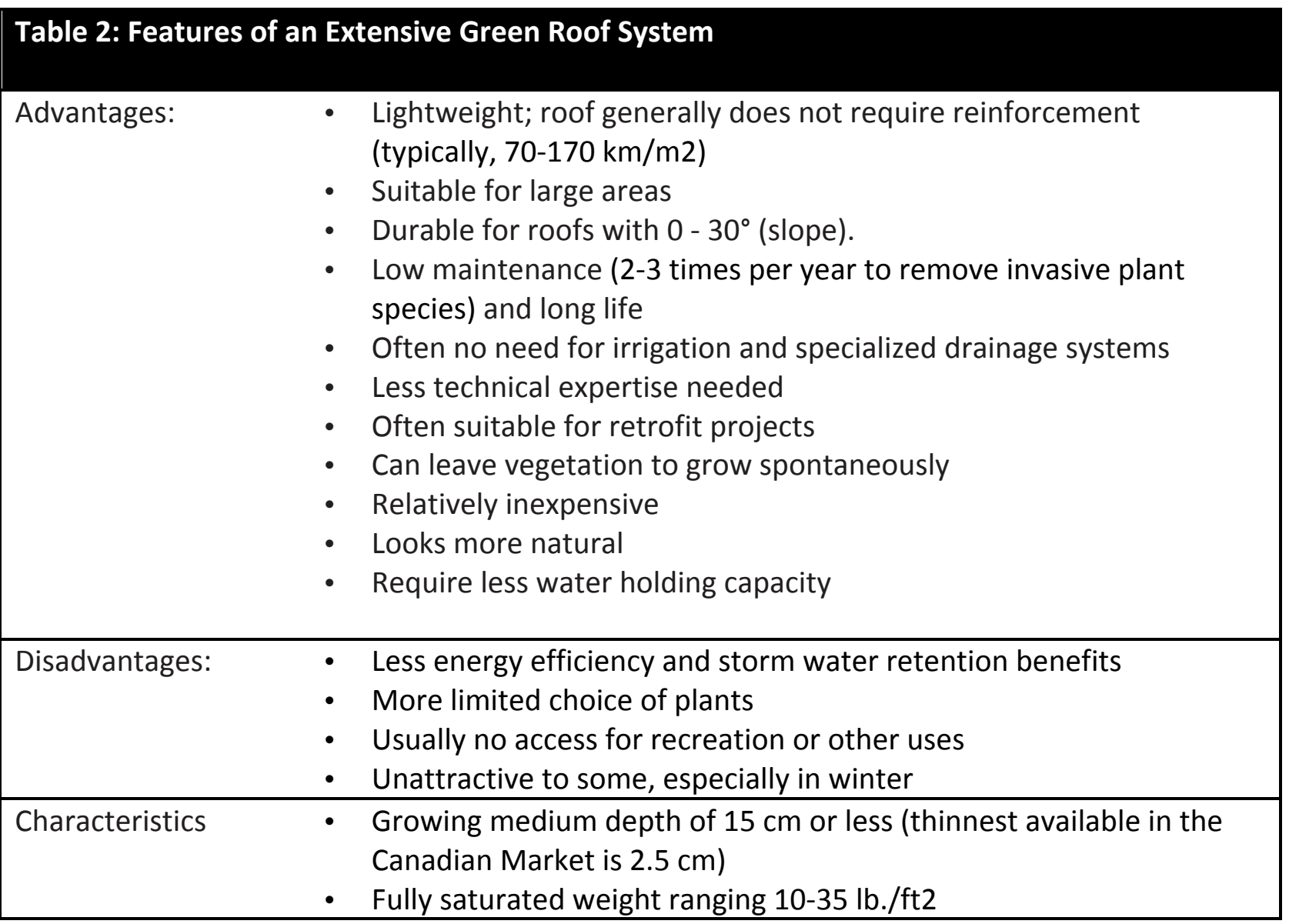

Source: Peck \& Kuhn, n.d.; Peck et. al., 1999; Peck, 2001; Bianchini \& Hewage, 2012; Lee, 2017

\subsubsection{INTENSIVE GREEN ROOFS}

Intensive green roof systems are usually accessible; contain deeper soil to support increased plant diversity and water retention leading to increased weight of the system (Peck \& Kuhn, n.d; Castleton, et. al., 2010). Intensive systems are associated with rooftop gardens and support vegetation such as grasses, herbs, shrubs, small trees, fruit trees and vegetables (Bianchini \& Hewage, 2012). They generally require more maintenance and irrigation, driving up associated costs (Peck, 2001; Lee, 2017). The advantages and disadvantages of intensive green roofs are outlined in table 3: 


\begin{tabular}{|c|c|}
\hline Advantages: & $\begin{array}{l}\text { - Greater diversity of plants and habitats } \\
\text { - Good insulation properties } \\
\text { - Can simulate a wildlife garden on the ground } \\
\text { - } \text { Often accessible, with more diverse utilization of the roof. (i.e. for } \\
\text { - } \text { recreation, growing food, as open space } \\
\text { - Lore energy efficiency and storm water retention capability } \\
\text { - }\end{array}$ \\
\hline Disadvantages: & $\begin{array}{l}\text { - } \text { Greater weight loading on roof } \\
\text { - } \text { meed for irrigation and drainage systems requiring energy, water, } \\
\text { - } \quad \text { Higher capital \& maintenance costs } \\
\text { - } \quad \text { More complex systems and expertise }\end{array}$ \\
\hline Characteristics & $\begin{array}{l}\text { - Growing medium depth of more than 6" (varies between } 20 \mathrm{~cm} \text { and } \\
120 \mathrm{~cm} \text { ) } \\
\text { - } \quad \text { Irrigation required } \\
\text { - } \quad \text { Fully saturated weight ranging } 35-300 \mathrm{lb} . / \mathrm{ft} 2 \\
\text { - Drainage layer is usually } 4 \mathrm{~cm} \text { or more in thickness; round pebbles } \\
\text { are typically used for natural drainage }\end{array}$ \\
\hline
\end{tabular}

Source: Peck \& Kuhn, n.d.; Peck et. al., 1999; Peck, 2001; Bianchini \& Hewage, 2012; Lee, 2017)

\subsubsection{SEMI-INTENSIVE GREEN ROOFS}

Semi-Intensive green roofs are sometimes referred to as a hybrid and are a composed of characteristics featured in extensive and intensive green roofs (Peck, 2001). However, to be officially classified as such, the total green roof area of the system has to be comprised of $25 \%$ or less extensive green roof (Bianchini \& Hewage, 2012). The characteristics of semi-intensive green roofs vary, however the system typically supports a higher diversity of plants than extensive systems and has a higher attributed cost (Lee, 2017). 


\subsection{COOL ROOFS}

Due to the high costs associated with green roofs, alternative strategies to combat challenges of urbanization have been widely sought. As a result, cool roof technology has gained much prominence in recent years. Cool roofs involve the addition of a reflective layer or coating above a conventional roof in order to reflect rather than absorb solar radiation (William et. al., 2016). The capacity of this layer to absorb radiation from the sun is measured through the Solar Reflectance Index (SRI). Cool roofing materials in Toronto are required to have an SRI value of 78 (City of Toronto 2013a). The costs associated with cool roofs are similar to traditional roofs, in regards to both installation and maintenance (William et. al., 2016). However, cool roofs provide a reduced assortment of benefits in comparison to green roofs, primarily targeting a reduction in rooftop temperatures. As a result they also have a weaker ability for temperature regulation in colder seasons, requiring increased energy costs in colder climates due to lack of insulation and reflection of solar rays (ibid). 


\subsection{GREEN ROOF BENEFITS}

\subsection{ENVIRONMENTAL BENEFITS}

Green roofs positively contribute to the urban environment in a variety of ways. Urban built form has resulted in an increase in temperatures through the absorption and emission of radiated solar heat by buildings, pavement, and other urban surfaces during the day, which is then released back into the atmosphere at night (Lehmann, 2014). This is known as the urban heat island effect. Green roofs are known to reduce this effect as vegetation and plants provide cooling and shading as well as reduce heat through evapotranspiration (Carter \& Fowler, 2008; Lehmann, 2014). It has been estimated that cities with $50 \%$ to $60 \%$ of rooftops consisting of green roofs have the ability to lower summertime temperatures by approximately five degrees Celsius (Forbes, 2010). A previous study by Environment Canada found that "greening 6\% of available roof space in Toronto would reduce summer temperatures by $1^{\circ} \mathrm{C}$ to $2^{\circ} \mathrm{C}$ overall," (Foster, Lowe, \& Winkelman, 2011, 7).

Green Roofs also improve air quality through reducing air pollution (Carter \& Fowler, 2008; Peck et. al., 1999; Forbes, 2010). A study of the City of Chicago found that approximately 20 hectares of green roof in the city could remove a total of 1.675 kilograms of air pollutants a year (Kim, Hong, Koo, 2012, 8476). Green roof vegetation also has the ability to reduce carbon dioxide and green house gas (GHG) emissions by lessening heating and cooling demands and sequestering carbon from the urban environment (Li, 2013; Foster, Lowe, \& Winkelman, 2011). Green roof systems have been found to sequester 375 grams of carbon (Kim, Hong, Koo, 2012, 8476).

Green roofs are also an important component for stormwater management. Urban areas covered in impermeable surfaces are vulnerable to flood risk as the frequency and intensity of 
precipitation worsens due to climate change (Mees \& Driessen, 2011). Green roofs absorb large amounts of rainfall and stormwater runoff (Forbes, 2010), aiding to reduce the overburdening of storm sewer systems. This also lowers the risk of Combined Sewer Overflow (CSO), in cases where combined sewer systems are in place. A Combined sewer system is where storm drains and sanitary sewer lines connect; when this system reaches capacity, partially treated or raw sewage discharge into water bodies, polluting water sources (Binstock, 2011). Ontario has 107 combined sewer systems and in 2006 and 2007 alone, there were more than 1000 instances of CSO (Binstock, 2011). Stormwater management is a grave issue in Toronto as climatic changes expect to bring increased amount of rainfall to the region. Foster, Lowe, \& Winkelman (2011) note that in 2005 heavy rainfall in Toronto resulted in mass flooding leading to approximately $\$ 400$ million in damages to public and private property, including $\$ 40$ million dollars for the "Finch Avenue washout" where flooding waters caused a road collapse (2). Green roofs have been widely acknowledged as part of the solution in addressing stormwater management concerns due to climate change impacts. They can on average reduce annual stormwater run-off by 50-60\% (Foster, Lowe, \& Winkelman, 2011, 6).

Green roofs also create habitat for wildlife (Li, 2013; Peck et. al., 1999; Forbes, 2010) and have the potential to increase biodiversity (Carter \& Fowler, 2008; Lehmann, 2014). Currie \& Bass (2010), discuss the role and importance of increasing biodiversity through green roofs in Toronto, and find that they are able to mimic natural habitats and are important for endangered species.

\subsection{SOCIAL BENEFITS}

Green roofs are recognized for creating green amenity spaces in built up urban areas (Li, 2013). It is important to note that design considerations may inhibit access to green roofs as an amenity space; however, it is possible to create access to green roofs for the purposes of social 
gathering rather than maintenance alone. Increased green amenity spaces can positively impact mental health by creating more natural space for social interaction and through providing an inherent aesthetic value (ibid). Green roofs can also reduce noise pollution in buildings up to two storeys (ibid). As the height of buildings increase this ability is reduced.

Furthermore, improved air quality, a reduction in greenhouse gas emissions, stormwater quality improvements, and other benefits significantly improve public health outcomes (Peck et. al., 1999, 9). Additionally, the improved aesthetics enhance livability and thus improve human health and wellbeing (Green Infrastructure Ontario, n.d.).

Green roofs also contain educational opportunities. This is extremely relevant to the case for adoption of green roofs across public schools in Ontario. Kudryavtev, Krasny, \& Stedman (2012) studied the impact of urban environmental education programs on youth in a New York City neighbourhood and found that interventions such as environmental education can nurture a sense of place and foster environmental awareness and behaviors (9). Li (2013) argues that green roofs provide an opportunity for students to learn about plant science, wildlife habitat, water cycles, and much more. She suggests that green roofs can become part of an important interactive program that teaches students about nature and life sciences, instilling environmental knowledge. Two case studies in the United States were used to illustrate this point, both existent in New York City: Bronx Design and Construction Academy and Calhoun School. The former was funded through grants from the City garden club and New York State Department of Environmental Conservation, and the latter was built as an addition to an existing school building. Both schools incorporated the green roofs within various 
programs, including "environmental science, plant biology, and ecology" (Li, 2013, 39). This demonstrates that there is an intersection between green roofs and educational benefits.

\subsection{ECONOMIC BENEFITS}

Green roofs produce economic benefits for the green economy, and for private developers and property owners. For the former, the expansion of green roof policies suggests that there will be a rising need within the market for the green construction sector. This need results in employment opportunities in the construction, maintenance, and engineering of green roofs (Merk, et. al., 2012; Kim, Hong, \& Koo, 2012). For the latter, green roof implementation results in lower HVAC costs, reductions in energy costs by way of by shading and evaporative cooling in the summer and insulation in the winter (Merk, et. al., 2012; Peck et. al., 1999). On a Municipal level, green roofs can help save millions of dollars in flood losses (Green Infrastructure Ontario, n.d.).

Exploring the economic benefits that green roofs can produce is vital to this study. It creates a strong case for implementing green roofs policies, as costs of green roofs are typically the prime barrier faced in implementation (Lee, 2017). Green roofs are part of the green economy, and policy expansion in this area results in expansion within the industry. Consequently, green roof policy expansion can lead to increased job creation (Kim, Hong, \& Koo, 2012). A recent report released by the Federation of Canadian Municipalities (2011) outlines six priority areas for building Canada's green economy. Green roofs can be identified in two of these six areas: energy efficiency of buildings and water conservation and wastewater treatment. Since buildings are a major source of GHG emissions, they state that an increase in energy efficiency of buildings can reduce operating costs as well as boost the economy. As previously, green roofs can produce such improvements in 
energy efficiency through reduction in heating and cooling within buildings. Additionally, stormwater management benefits play a large role in preventing CSO's, which affect wastewater.

The adoption of green roofs can result in numerous cost savings for property owners, businesses, and municipalities. Through increasing energy efficiency green roofs cause: "savings in grey infrastructure needs, reduction in health investment due to air quality improvement, reduction in energy consumption, and relief of urgency of climate changes and global warming" (Li, 2013, 34). Prior to implementing a by-law, the City of Toronto estimated that green roof installations citywide could save an initial $\$ 313,100,000$ and $\$ 37,130,000$ annually (Foster, Lowe, \& Winkleman, 2011). Table 4 displays the breakdown of these savings:

\begin{tabular}{|l|l|l|}
\hline \multicolumn{2}{|l|}{ Table 4: Estimated City-wide Potential Value of Green Roofs in Toronto } \\
\hline Category of Benefit & Initial Cost Saving & Annual Cost Saving \\
\hline Stormwater & $\$ 118,000,000$ & - \\
\hline Combined Sewer Overflow & $\$ 46,600.000$ & $\$ 750,000$ \\
\hline Air Quality & - & $\$ 2,500,000$ \\
\hline Building Energy & $\$ 68,700,000$ & $\$ 21,560,000$ \\
\hline Urban Heat Island & $\$ 79,800,000$ & $\$ 12,320,000$ \\
\hline Total & $\$ 313,000,000$ & $\$ 37,130,000$ \\
\hline
\end{tabular}

Source: (Banting, et. al., 2005; Foster, Lowe, \& Winkelman, 2011).

For property owners, including school boards, a green roof may have an initially higher cost to install, however, the reduction in energy costs, increase in property values and lifetime savings due to extended roof life can offset these costs in the long run. In 2006, a University of Michigan study found that installing a green roof would cost $\$ 464,000$ while a conventional 
roof would cost $\$ 335,000$; but that the green roof would result in $\$ 200,000$ of savings over the long run through reduced energy costs alone (Foster, Lowe, \& Winkelman, 2011). A cost benefit analysis of the City of Portland's green roof program determined that "green roofs on public buildings were estimated to provide net-benefit of $\$ 191,000$ from reduced operations and maintenance costs" (Foster, Lowe, \& Winkelman, 2011, 9). In the context of school infrastructure, Weekes (2009) determined that it costs approximately $\$ 8$ billion dollars to heat and light school across the United States (256). He concluded that green schools would be a viable investment and solution to reduce energy costs and lower maintenance needs, through new design and construction as well as renovation and restoration of existing buildings (Weekes, 2009, 257). 


\subsection{POLICY DEVELOPMENT}

The City of Toronto is a leader in green roof policy and procurement in North America, being the first to initiate a by-law to enforce green roof construction. This section will explore the process of green roof policy development in the City. The importance of evaluating this process lies in the ability to assess the role of Toronto School boards in the development of green roof regulation. Uncovering the extent to which school boards where involved in this process allows deeper insight into the issues school boards have faced regarding green roof implementation.

\subsection{CITY OF TORONTO'S GREEN ROOF STRATEGY}

The City of Toronto's green roof policy initially emerged from three environmental policies: Toronto's Official Plan, the 2000 Wet Weather Flow Management Master Plan, and the 2001 Environmental Plan (Banting, et. al., 2005; Lawlor et. al., 2006; Lee, 2017). The 2000 Wet Weather Flow Management Master Plan identified a need to find strategies that aim to prevent and reduce stormwater run-off within the City (Lawlor et. al., 2006). The 2001 Environmental Plan identified a need for strategies that aimed to encourage green roofs and gardens to aid in the reduction of the urban heat island effect (ibid). Finally, Toronto's Official Plan acknowledged the need for solutions that would address the City's environmental issues in areas such as stormwater management. To accomplish the aforementioned goals, the City conducted A Toronto Green Roof Feasibility Study (2000) that led to support for and the construction of two green roof demonstration projects, located at Toronto City Hall and the Eastview Community Center (Lawlor et. al., 2006). This led to the pursuit of extensive 
stakeholder engagement and public meetings regarding the implementation of green roofs within the City, as well as a green roof cost-benefit analysis for the City of Toronto conducted by Ryerson University (ibid). On November 23, 2005, the findings and proposed options for green roof implementation were presented as a discussion paper-Making Green Roofs Happen - prepared by the City's planning department to Toronto's Roundtable on the Environment (Lee, 2017; City of Toronto, 2008a). As a result of a set of recommendations from Toronto's Roundtable on the Environment, City Council adopted a Green Roof Strategy on February 1, 2006. The initiatives of the strategy were categorized in four ways (City of Toronto, 2008a):

I. Introduction of a pilot incentive grant program to encourage green roof construction;

II. Installation of green roofs across City owned and operated buildings;

III. Identification of the development process as a means to encourage green roofs;

IV. Need to enhance public education and promotion

\subsubsection{GREEN ROOF PILOT INCENTIVE PROGRAM}

In 2006, a pilot incentive program was initiated, resulting in the construction of 16 green roofs Citywide (Lawlor et. al., 2006). The program was funded by Toronto Water (an allocation of $\$ 200,000$ in 2006 and 2007) granting $\$ 10$ per square meter of eligible green roof area on city buildings as well as those built by the private sector (City of Toronto, 2008b). In 2007, the program increased its allocation to $50 \$$ per square meter of green roof installed, and expanded its application to institutional, commercial and industrial development on a one year pilot basis (City of Toronto, 2008b). It also established a funding cap of $\$ 10,000$ for residential projects, 
and $\$ \mathbf{1 0 0 , 0 0 0}$ for institutional and commercial projects (City of Toronto, 2008b). By the end of 2007, the program aided the development of 46 green roof projects in the City (City of Toronto, 2008c).

\subsubsection{USE OF THE DEVELOPMENT PROCESS TO ENCOURAGE GREEN ROOFS}

To encourage the construction of green roofs through the development process, in 2007, the City of Toronto approved zoning by-law amendments and site plan control applications in regards to 14 sites (Lee, 2017). Amongst the sites, four were commercial buildings, eight were mixed-use buildings (residential and commercial), two were condominiums, one senior complex, one live work unit and finally, and one school building (City of Toronto, 2008a).

\subsubsection{GREEN ROOFS INSTALLATION ON CITY OWNED BUILDINGS}

As part of the Green Roof Strategy, green roofs were to be installed on city-owned buildings and facilities during roof replacement or on new construction, where it could be deemed feasible and practical (City of Toronto, 2008a). Later, the term feasible was removed from the strategy as the cost for new facilities considering green roof construction could be accounted for in capital budgets. However, "practicality" remained since structural or technical issues could impact opportunities for green roof construction on existing facilities (ibid). New build city facilities have since become subject to the Toronto Green Standard (TGS), under which they must incorporate green roof construction. 


\subsubsection{PUBLIC EDUCATION AND PROMOTION}

To promote green roof construction and enhance awareness of green roof benefits across the City, multiple initiatives were implemented. Firstly, the City launched a green roof website where information regarding green roofs, the incentive program and links to relevant websites, contact information and the cost benefit analysis conducted were disseminated. Furthermore, two training sessions were held for City staff in various departments such as City planning and Toronto Building to teach staff about green roof benefits, design and construction. The City also held an additional session for Toronto School Boards.

\subsection{THE ROLE OF TORONTO SCHOOL BOARDS IN POLICY DEVELOPMENT}

Toronto School Boards were engaged early in the policy development process, through the four phases of the Green Roof Strategy. It was identified early on that schools presented a great opportunity to achieve many of the benefits that green roofs can provide. In fact, the recommendations put forth by the Roundtable on the Environment in 2005 suggested that the City of Toronto invite the Toronto District School Board to develop a green roof implementation program that could promote "educational benefits to students, in addition to all other benefits" (City of Toronto, 2006). As part of the Green Roof Strategy, the City also held an individual information session for School Boards in order to increase awareness and education of green roof benefits, designs and construction. By doing so the City showcased the importance of incorporating one of the biggest property owners within the City in the consideration towards a successful policy outcome. 
However, consultation proceedings held in 2008 and 2009 revealed that school boards were concerned about meeting the requirements of green roof regulations to come. Public and separate boards raised concerns about having the financial capacity to incorporate green roofs in new developments as well as existing building sites. They claimed that the Ministry of Education does not factor these extra costs when providing capital funding for school construction (City of Toronto, 2012a). They worried that the installation of green roofs would impact the availability of funds for landscape improvements at grade, which were guaranteed to be accessible to students and visually enhance school grounds (ibid). The City's initial reaction to this was to request that the province amend the funding formula for schools to account for extra costs incurred from green roof installation. While Council put this recommendation forth, the Ministry of Education did not address the concerns identified and informed the City that no additional funding would be provided to aid schools in meeting the requirements of the by-law. 


\subsection{CURRENT CONTEXT}

\subsection{TORONTO'S GREEN ROOF BY-LAW}

\subsubsection{ESTABLISHING AUTHORITY FOR REGULATION}

The City of Toronto Act, 2006 (COTA) came into effect on January 1, 2007, establishing a broad legislative framework for the City. COTA was an attempt to balance the interests of the province and the City, acknowledging the City's needs and allowing Council the means to respond to them. It equipped Council with the power to establish by-laws to govern issues relating to health safety as well as economic, social and environmental wellbeing (Ministry of Municipal Affairs, 2015). COTA provided the City of Toronto with an alternative method of establishing green roofs, beyond the approaches identified in the Green Roof Strategy.

Prior to its adoption, Section 35 of the Ontario Building Code Act, 1992 prevented the City of Toronto from requiring the construction of green roofs by mandating that municipal bylaws not exceed the requirements set out in the provincial building code (City of Toronto, 2007a). Since the building code lacked direction for green roof standards, the City of Toronto was restricted in passing a by-law to govern their construction. Section 108 of the City of Toronto Act, 2006 (see figure 2), allowed the City an exemption from the aforementioned building code regulation, creating the opportunity to utilize regulatory tools for green roof implementation (City of Toronto, 2007a). 
Figure 2: Construction Of Green Roofs Or Alternative Roof Surfaces (COTA excerpt)

Structures, Including Fences and Signs

108 (1) "authorize the City to pass a by-law requiring and governing the construction of green roofs or of alternative roof surfaces that achieve similar levels of performance to green roofs if the provisions of the by-law do not conflict with the provisions of a regulation made under the Building Code Act, 1992 respecting public health and safety, fire protection, structural sufficiency, conservation and environmental protection and the requirements respecting barrier-free access." 2006, c. 11, Sched. A, s. 108 (1); 2006, c. 32, Sched. B, s. 22 (1); 2009, c. 33, Sched. 21, s. 4 (5).

\section{Same}

(2) A by-law under subsection (1) prevails over a regulation made under the Building Code Act, 1992, despite section 35 of that Act. 2006, c. 11, Sched. A, s. 108 (2); 2006, c. 32, Sched. B, s. 22 (2).

Source: City of Toronto Act, 2006, SO 2006 c. 11.

\subsubsection{ESTABLISHING CONSTRUCTION STANDARDS}

Due to the building code's silence on green roofs, the City of Toronto had to establish minimum green roof construction standards to guide green roof development in the City, while still adhering to building code regulations. Additionally, recommendations produced during the development of a framework for public review and engagement for the City's Climate Change and Clean Air Action Plan 2007 (see table 5) called for the establishment of mandatory green building standards for new buildings, businesses and residences by the year 2012 (City of Toronto, 2007b).

\begin{tabular}{|l|l|}
\hline Table 5: Change is in the Air: Toronto's Climate Change and Clean Air Action Plan \\
\hline Natural Gas & Supporting Actions \\
\hline Potential Action & $\begin{array}{l}\text { 1. Include information on green building } \\
\text { standards with building permits for } \\
\text { renovations. }\end{array}$ \\
\hline And small businesses by 2020 & 2. Provide financing incentive for green \\
\hline
\end{tabular}




\begin{tabular}{|l|l|}
\hline & roofs. \\
\hline $\begin{array}{l}\text { Invite bids to develop renewable energy } \\
\text { systems on city-owned properties }\end{array}$ & No supporting actions identified \\
\hline $\begin{array}{l}\text { Mandatory green building standards for new } \\
\text { buildings including businesses and residences } \\
\text { by no later than } \mathbf{2 0 1 2}\end{array}$ & No supporting actions identified \\
\hline
\end{tabular}

Source: (City of Toronto, 2007b)

In January 2006, Halsall Associates Limited was commissioned by Toronto Building to conduct technical research that would provide the foundation for the development of a green roof building standard (City of Toronto, 2007a). The culmination of this research was presented in the Green "vegetative" Roof Building Standard for the City of Toronto report. The report aimed at identifying (a) the requirements of the Ontario Building Code Act that applied to the construction of green roofs, (b) established standards in other jurisdictions for green roof regulation, (c) and to create a preliminary framework for the incorporation of standards into a green roof by-law (City of Toronto, 2007a). From 2008 to 2009, the report was made available for consultation and technical review, specifically targeting professionals in the green roof industry, designers, developers, building owners, and similar stakeholders. Furthermore, a Green Roof Technical Advisory Committee comprised of green roof experts was established to guide potential amendments arising from consultation feedback.

\subsubsection{ESTABLISHING REGULATION}

The results of the aforementioned processes led to the development of a draft Green Roof By-law, including the Toronto Green Roof Construction Standard (TGRCS) considered by the Planning and Growth Committee on April 14, 2009. The Committee recommended that City Council amend the City of Toronto Municipal Code to require and govern the construction of 
green roof (City of Toronto, 2009a). Other important recommendations put forth included the addition of the Chief Planner's ability to approve variances to the Green Roof By-Law and authorize that cash-in-lieu gathered through variances be directed into the Eco-roof Incentive Program (ibid). The Committee also suggested that Council request the province allocate additional funds to new schools in Toronto under the funding formula, to support Toronto public and private school boards in adhering to the new by-law. In May, City Council enacted the draft Green Roof By-Law and adopted the recommendations put forth by the Planning and Growth Committee to be applicable as of January 31, 2010 (ibid).

Chapter 492 of the Toronto Municipal Code now mandates the By-law (By-law 5832009). The Toronto Green Roof Construction Standard (TGRCS) was adopted into section 492-8 and 492-9. Its main purpose is to set out the minimum construction and maintenance requirement of green roofs, while still meeting the requirements of the Ontario Building Code (City of Toronto, 2013a). In 2017, the City also released Supplementary Guidelines for the Toronto Green Roof Construction Standard that aim to provide designers and other professionals better understanding of the standard's requirements. The guidelines complement the Green Roof By-law and provide green roof resources, best practices and other explanatory materials to aid industry professionals in adhering to the flexible design standards (City of Toronto, 2017c).

Chapter 492 generally lays out the requirement of green roofs for new commercial, institutional, industrial (constructed post April $29^{\text {th }}, 2012$ ) and residential development applicants, as well as permit applications for a new addition to an existing building constructed after January 30, 2010, both of which must exceed a gross floor area of 2000 meters squared 
(City of Toronto, 2013a). To be applicable, residential buildings must be more than 6 storeys or 20 meters in height. The construction requirements for green roof coverage are dependent on the size of the building and type of development, as displayed in table 6 .

\section{Table 6: City of Toronto Green Roof Requirement}

Gross Floor Area

(Size of Building)

$2,000-4,999 \mathrm{~m}^{2}$

$5,000-9,999 \mathrm{~m}^{2}$

$10,000-14,999 \mathrm{~m}^{2}$

$15,000-19,999 \mathrm{~m}^{2}$

$20,000 \mathrm{~m}^{2}$ or more

Source: (City of Toronto, 2013b)

The size of the green roof is dependent on the size of the available roof space, defined
Coverage of Available Roof Space (Size of Green Roof)

$20 \%$

$30 \%$

$40 \%$

$50 \%$
$60 \%$

in the Municipal Code as the:

total roof area of the building or addition excluding areas designated for renewable energy devices, private terraces (no greater than the floor of abutting residential unit at the roof level), and required outdoor amenity space of residential buildings (City of Toronto, 2013a).

\subsubsection{CASH-IN-LIEU PROCESS}

Chapter 492-11 and 492-12 of the City of Toronto Green Roof by-law enables applicants

to request either a complete exemption to opt out of providing a green roof or a variance to provide reduced green roof coverage, provided that a cash-in-lieu payment of $\$ 200$ per Meter Square $\left(\mathrm{m}^{2}\right)$ is made for the green roof area not being provided (City of Toronto, 2013a). This 
process requires that applicants submit a variance/exemption request letter to the Chief Planner outlining the cause underlying their inability to provide either a portion or the full green roof as required, as well as green roof statistics pertaining to the development. Statistics are comprised of the portion of green roof being proposed in square meters $\left(\mathrm{m}^{2}\right)$, the percentage of green roof proposed, the portion of green roof required in square meters $\left(\mathrm{m}^{2}\right)$, the percentage of green roof required, the available roof area as defined by the by-law, and the amount to be owed to the City. Applicants then await a notice of decision from the Chief Planner's office acknowledging the approval of the cash-in-lieu request. Following this notice, the applicant must provide the necessary funds as outlined in the notice of decision to the City.

\subsubsection{EXEMPTIONS}

Initially, industrial buildings, non-profit housing and schools were contemplated to be exempt from the proposed by-law due to concerns over the cost of green roof implementation. Due to the large size of most industrial buildings and policies protecting employment uses within the city, it was decided that industrial buildings would only need to provide a maximum green roof area of $10 \%$ of the total available roof area to a maximum size of $2,000 \mathrm{~m}^{2}$ (City of Toronto, 2009c). By reducing the size of green roofs required on industrial building, the City aimed to alleviate a large portion of the cost burden. The City also conducted a Green Roof Alternatives Study in 2010 that looked to identify alternative technologies or treatments that could achieve similar goals as a green roof at a lower cost. The study determined that no single alternatives could achieve this, however a combination of alternatives targeting the urban heat island effect and stormwater management objectives could potentially achieve similar outcomes (City of Toronto, 2012a). This led to an amendment in the green roof by-law to allow 
Industrial buildings the option of installing cool roofing materials for $100 \%$ of the available roof space (ibid). School buildings on the other hand, were not allotted any measures to reduce the cost of green roof implementation or given permissions for alternative measures.

\subsubsection{ESTABLISHING INCENTIVES}

In 2009, the City of Toronto launched the Eco-Roof Incentive program based on the success of the green roof pilot incentive program, providing direct incentives to encourage voluntary construction of green roofs (City of Toronto, 2008b). The level of funding was maintained from the pilot program, allocating an incentive of $\$ 50$ per square metre up to a maximum of $\$ 100,000$ towards voluntary green roof construction. Cool roofs were also now included in the incentive program, with an incentive ranging from two to five dollars per square meter up to a maximum of $\$ 50,000$ (ibid). In 2010 , the Eco-Roof Incentive Program was revised in order to be consistent with the Green Roof By-law as well as newly established green building standards in the City. The changes included the eligibility removal of new commercial and institutional buildings, instead opening up funding for commercial and institutional developments under 2000 meters squared of gross floor area, which are not captured by the Green Roof By-law (City of Toronto, 2010). In 2012, City Council established the 'Eco-Roof Financial Assistance Reserve Fund' to allocate the proceeds garnered through the cash-in-lieu policy towards grants for buildings eligible for the eco-roof incentive program (City of Toronto, 2012b). Additionally, to address issues that Toronto Public, French and Catholic Schools were still facing to meet the requirements of the Green Roof By-law, the City extended eligibility for the eco-roof incentive program to Toronto School Boards in 2012 (City of Toronto, 2012b). 
In 2013, the City revised the program by increasing the incentive level for the construction of green roofs to $\$ 75$ per square meter and granting residential buildings not covered under the by-law eligibility for funding (City of Toronto, 2013b). In 2016, the incentive level was increased once more up to $\$ 100$ per square meter. In addition, City Council added an additional grant to support structural assessments for green roof projects up to a maximum of $\$ 1000$ and added a requirement for City staff to submit recommendations for approval of funding requests greater than $\$ 50,000$ for cool roofs and $\$ 100,000$ for green roofs (City of Toronto, 2016). This funding cap was subsequently removed. In the same year the City once again requested the Government of Ontario to align school capital budget allowances to aid school boards in further meeting the green roof regulations, however this time they also asked that it be aligned with Ontario's own new Climate Change Strategy and Action Plan. This policy will be introduced and discussed in chapter 8.0. It is important to note that the Government of Ontario has still not taken any measures to support the above recommendation from Toronto City Council. 


\section{SECTION 2: ANALYSIS}

\subsection{QUANTITATIVE ANALYSIS}

To assess the extent of issues facing Toronto school boards in the implementation of green roofs, this study undertook an analysis of available data sources in order to: determine uptake of green roof installation on school sites captured by the by-law since it's inception and to examine the amount of school sites that have resorted to paying cash-in-lieu rather than installing a green roof.

\subsection{METHODOLOGY}

The review began with a search for Green Roof application data pertaining to Toronto Public School Boards from numerous sources, as collected by the City of Toronto. All site plan application data pertaining to Toronto Public School sites between January $31^{\text {st }}, 2010$ and October $27^{\text {th }} 2017$ were retrieved from the City of Toronto's Research and Information team in the Strategic Initiatives, Policy \& Analysis division. Sites with over 2000 square metres in proposed non-residential GFA were then extracted from this data set.

Green roof building permit data was also retrieved from Open Data Toronto, as provided by the Toronto Building Plan Review Section. This data set provides more in depth information regarding development details, such as a description of the application, the green roof area required and the green roof area provided. Applications pertaining to Toronto Public School Boards for green roof permits and variances were then extracted from this data set. 
Furthermore, data on documentation regarding Toronto School Board cash-in-lieu applications was retrieved from the City of Toronto's Environmental planning files.

Once all application building and site data was collected, data was sought from IBMS (City of Toronto's internal application tracking software) and the Application Information Center in order to verify and update information retrieved from previous sources. These documents include the variance or full exemption letter addressed to the Chief Planner that the applicant must provide through the cash-in-lieu process and the notice of decision issued by the Chief Planner's office in response. Finally, planners listed upon the applications were contacted directly in order to attain and retrieve the above documentation, if previously unavailable via other resources.

Once culminating data was collected and all necessary documentation regarding applications were sought, an analysis was conducted by cross-referencing site plan applications and green roof permit applications by Toronto School Boards. This was to determine the proportion of applications providing a full green roof, a partial green roof, or no green roof. Additionally, documentation pertaining to the cash-in-lieu process was analyzed to examine reasons behind opting to provide cash-in-lieu rather than providing a green roof on site.

\subsection{DATA ANALYSIS}

\subsubsection{ANALYSIS OF SITE PLAN APPLICATIONS FOR TORONTO PUBLIC SCHOOL BOARDS}

Between January $1^{\text {st }}, 2010$ and October $27^{\text {th }}, 2017$, there were 56 site plan applications for Public School sites within the City of Toronto. One entry was discarded from analysis as the site plan application was submitted prior to the effective enforcement date of the Green Roof 
By-law, thus resulting in 55 total site plan applications. Within this total, $49 \%(27 / 55)$ of site plan applications were captured by the Green Roof By-law. That necessitates approximately half of all Toronto Public school developments to have incorporated a green roof on 20 to $60 \%$ of the total available roof area. Figure 3 displays the breakdown of these applications:

\section{Figure 3: Toronto Public School Site Plan Applications Requiring Green Roof Installations}

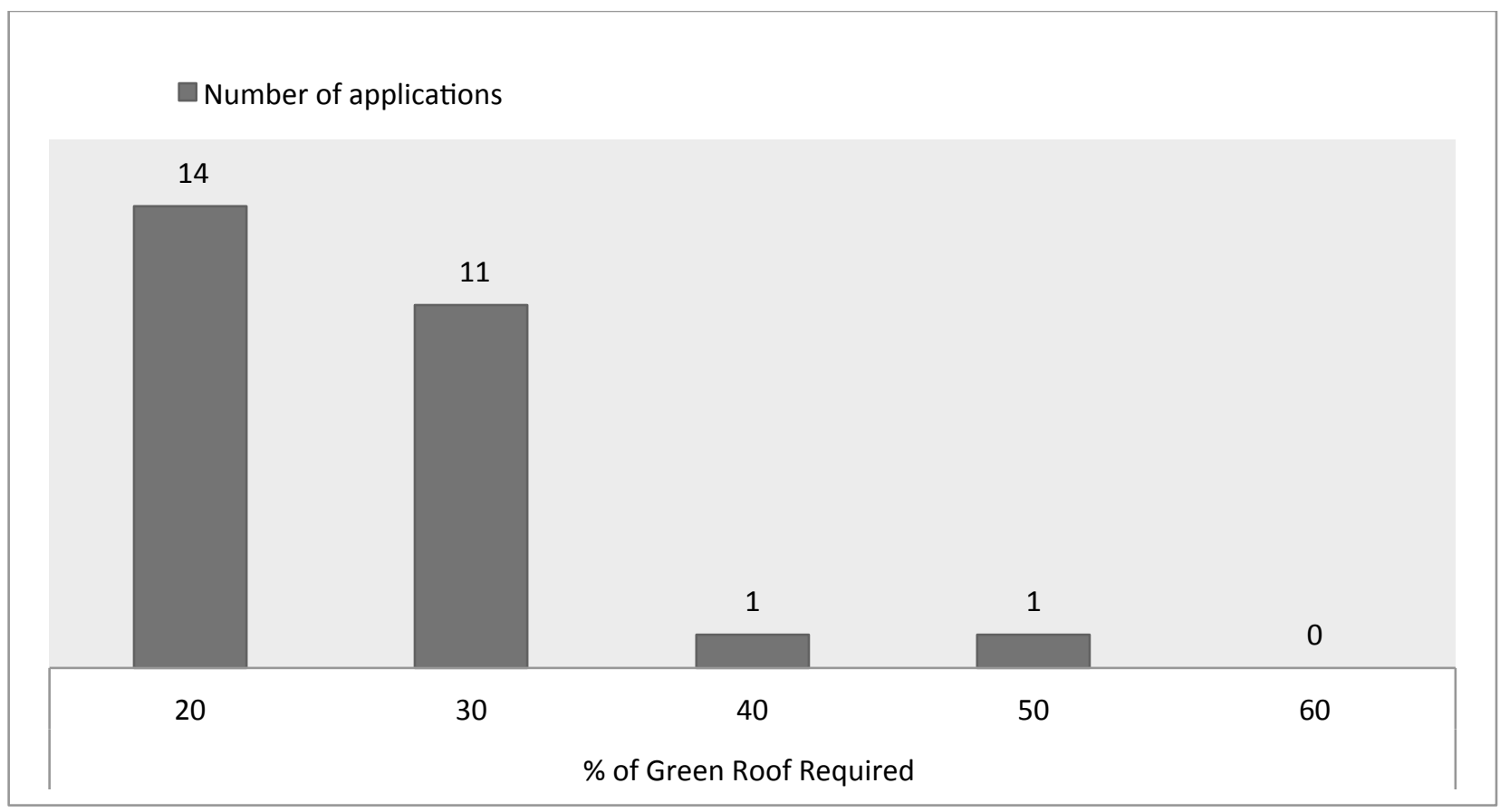

Most of the proposed public school developments ranged between $2000 \mathrm{~m} 2$ to 9,999 $\mathrm{m} 2$, requiring a total of $20-30 \%$ of the available roof area to incorporate a green roof. The majority of applications sought new building permits, as opposed to a building addition or alteration permit, as shown in figure 4: 
Figure 4: Toronto Public School Site Plan Applications Requiring Green Roof Installations by Building Type

\footnotetext{
New building Permit $\quad$ Building Addition or Alteration Permit
}

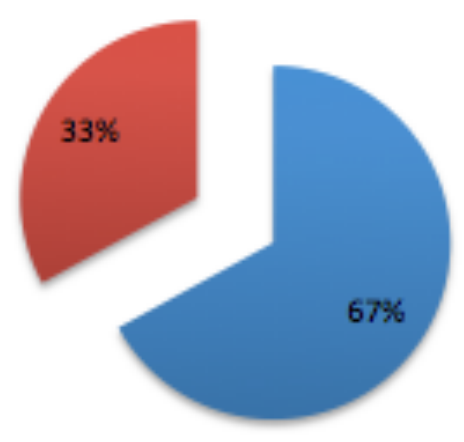

This is important to note, as there are less barriers involved with incorporating a green roof in new building designs rather than in a retrofit (Peck, 2001), where the structural capacity of the roof may be an issue and costs associated with installation are more significant.

\subsubsection{ANALYSIS OF GREEN ROOF PERMIT APPLICATIONS}

Following this stage, green roof permit applications pertaining to public school developments in Toronto were analyzed against the site plan application data in the former stage. According to the open data set on green roof permits, since inception of the Green Roof By-law 464 applications have been required to install a green roof. Applications by Toronto School Boards constituted for 27 of the total number of applications. However, these entries did not fully correspond to the site plan data analyzed. While both data sets display 27 school applications, three entries in each data set are missing from the other. Two applications from the site plan data set were subsequently added to the green roof permits data set, as documentation retrieved from the application information center gave insight on whether they 
met the requirement of the by-law. One application was removed from the analysis below, as no sources existed to verify the details of the application. Due to the low quantity of applications and in an effort to prevent misrepresentation or skewed results, no entries were removed from the open data set within the analysis.

Amongst the 29 applications, 55\% (16/29) met the requirements of the by-law. However, 45\% (13/29) did not meet the full requirements of the by-law; either providing reduced green roof coverage or no green roof coverage on site, instead opting to pay cash-inlieu of the requirements. This accounts for nearly half of all Toronto public school site plan applications. More than a quarter of these applications did not incorporate any green roof within the development. The breakdown of these applications is displayed in figure 5:

Figure 5: Breakdown of Green roof coverage of permit applications by Toronto Public Schools

EPartial Green Roof $\quad$ Eull Green Roof $\quad$ No Green Roof

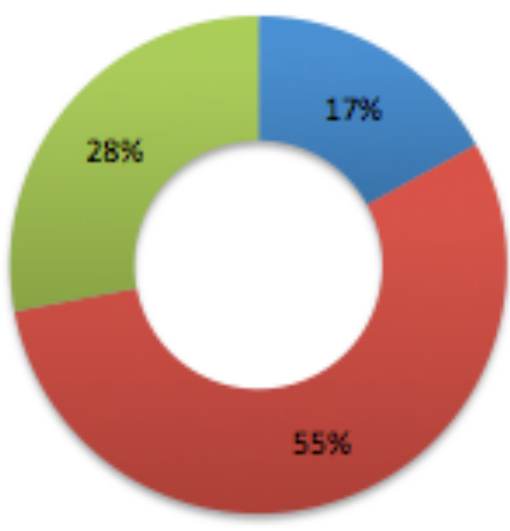


Amongst the thirteen applications that did not meet the by-law requirements, $69 \%(9 / 13)$ were concerning new building permits while only $31 \%$ (4/13) sought building renovation or alteration permits. As previously mentioned this is concerning considering that the ability to install green roofs on new buildings is an easier process than in building retrofits.

\subsubsection{ANALYSIS OF CASH-IN-LIEU DOCUMENTS}

Cash-in-lieu documentation was retrieved for twelve of the thirteen Toronto Public School green roof permit applications that sought an exemption from the green roof by-law. Documentation for three of these twelve applications failed to provide any rationale as to why a decision was made to opt out of providing a green roof. A comprehensive list of the rationales for each application is located in the appendix. This section will present a distilled version of this.

The most pressing issue that hindered the incorporation of a green roof on public school sites was maintenance costs. A scan of the documentation revealed that six applications listed maintenance as a consideration when deciding to opt out of providing a green roof. Two of these applications stated that as a result of the configuration of the roof space, a green roof would have to be installed as fragmented pieces, contributing to higher maintenance costs. Four stated that funding from the Ministry of Education is not enough to cover the maintenance costs, making it difficult to meet ongoing costs. In addition, rationales stated that in the face of competing annual budget demands, costs for other school programming at grade and extensive roof replacement backlogs, a decision to provide a green roof would be unjustifiable. One application stated that they would utilize funds provided by the City of 
Toronto through the Eco-roof incentive program, however, they cite that the program also provides no funding consideration towards maintenance costs.

Moreover, five applications list an assortment of other environmental measures taken on site in order to justify not incorporating a green roof within the development. These actions included at grade improvement such as the addition of permeable sodding, the retention of rainwater for reuse, tree planting, high albedo paving, effective ventilation, efficient heating and cooling systems and more. It is important to note that many of the additional features listed are necessitated within new developments through requirements of the Toronto Green Standard (TGS). Additionally, many of the benefits listed through a variety of measures could simply be achieved through the incorporation of a green roof on site. Furthermore, three applications listed that cool roofs would be incorporated in the development instead, as it would be a more cost effective option in achieving a reduction in the urban heat island effect. Three applications listed that instead of a green roof the development would incorporate the addition of photovoltaic systems. One application indicated the current existence of solar panels on an existing building as justification towards not considering a green roof. However, it should be noted that the Green-roof by-law does allow the elimination of roof space allocated to solar panels from the available roof space calculations.

Finally, two applications mentioned that a green roof would be a negligible teaching opportunity for students. Considering the limited resources of the board, they concluded that at grade improvements would be much more beneficial to students as well as the broader community. Nonetheless, one application seeking only a partial exemption noted that the 
green roof provided would be dispersed across two locations on site, directly above the ground floor and above the second floor. They stated that the former would be accessible to students and used as part of a Food Share Urban Farm, allowing students to utilize the space as a learning opportunity. The green roof on the latter location would be placed strategically in order to be viewable from the library, allowing students to directly benefit from the exposure to green space. This suggests that the opportunity does exist to utilize green roofs on school properties for educational purposes, directly benefiting the students therein.

\subsection{LIMITATIONS OF REVIEW}

The quantitative and qualitative analysis presented within this study was restricted by multiple factor. The limitations of the study are presented below:

1. The cash-in-lieu data set retrieved from Toronto's Open Data Catalogue is outdated. City staff from Toronto Building are responsible to coordinate and update the list according to incoming applications, however this is challenging, as it requires interdepartmental coordination and updates are not frequently tracked. While only 464 green roof permit applications existed, other sources suggest that this number should be well over 600 .

2. In total 13 Green-roof CIL applications were collected pertaining to school boards, however, documentation for one application could not be located through the resources utilized. Additionally, discrepancies were found in documentation pertaining to five cash-in-lieu applications, concerning minor inconsistencies to the green roof area required and proposed as well as no tracked cash-in-lieu payments in the City of Toronto's internal application tracking software (IBMS). Potential reasons for this include the fact that CIL payments are 
required at the time of final permit issuance, and some applicants could have decided not to proceed with the development, alter the application, or to adhere to the by-law. Due to time constraints and lack of resources these discrepancies could not be investigated fully.

3. Time constraints were a barrier in the analysis, affecting the ability to receive and utilize other resources for data analysis such as eco-roof incentive program data. Without this, it is unclear how many applications utilized the eco-roof incentive program towards implementation of a green roof or cool roof. 


\subsection{BARRIERS TO GREEN ROOF IMPLEMENTATION}

\subsection{GENERAL BARRIERS}

Although green roofs are acknowledged widely for the benefits they produce in both the private and public realms, there are still major barriers to widespread implementation. While these are often dependent on location, policies, incentives, climate and structure, some general barriers can be identified that range across these factors. Unfortunately, "little studies have been given to examining the major barriers that hinder the green roof applications"(Zhang., et. al, 2012, 315). This section will explore the general barriers in green roof uptake identified through available literature, and identify actions that the City of Toronto has taken, if any, to address them.

It is important to note that City of Toronto staff took some measures to ascertain and tackle some barriers early in the policy development process. They aimed to identify potential and existing barriers through public consultations with green roof stakeholders and support for an extensive report on the Environmental Benefits and Costs of Green Roof Technology for the City of Toronto (Lee, 2017; Banting, et. al., 2005). These barriers were shared in the report submitted to the Roundtable on the Environment, in order to influence better policy design. Many of the decisions and measures taken in the policy development stage correspond to the barriers identified in this section. Detailed explanation of these will be revealed below.

\subsubsection{LACK OF INFORMATION, AWARENESS AND UNCERTAINTY}

One consideration that often affects the lack of uptake on green roof technology is the uncertainty and lack of awareness of the benefits and costs associated with adopting green roof 
systems. This acts a strong barrier against private investment and action (Mees, et. al. 2012; Adger et al., 2009; Gifford, 2011; Mendelsohn, 2000). There is a general lack of awareness of maintenance costs and requirements, making building owners uncomfortable with the uncertainty of accepting such costs (Vijayaraghavan, 2016). It is oftentimes difficult for building owners to obtain an upfront estimate on their return on investment, and when such information is available, it could be complex and hard to comprehend (ibid). Additionally, qualitative benefits of green roofs such as increased amenity space, aesthetics, ecological and psychological benefits are difficult to quantify (Getter \& Rowe, 2006). This results in less knowledge for building owners of what these benefits could translate into. Moreover, a lack of understanding of the benefits of green roofs extends across various stakeholders. Peck et. al. (1999) suggested that policy makers, the development industry, professionals, researchers and the general public need access to detailed information (both quantifiable and qualitative) regarding the benefits of green roofs. Getter \& Rowe (2006) advise that lack of awareness of green roof benefits and costs can be alleviated through education as well as industry growth in North America.

The City of Toronto initiated demonstration projects early in the policy development phase in order to overcome identified informational barriers in the market place, including lack of financial and technical data (Banting, et. al., 2005). The green roof produced atop City Hall and the Eastview Community Center resulted in opportunities for research and production of reliable data in the Toronto Context. Specifically, it factored green roof "performance in areas such as energy efficiency, stormwater retention, the extension of roof membrane life span and plant survival" (Banting et. al, 2005). In addition, as previously mentioned in the policy 
development chapter, the City also implemented multiple initiatives to enhance public education and promotion of green roof benefits. This included the creation of a green roof website as well as information sessions. However, a review of the Eco-Roof Incentive Program by Lura Consulting in 2016, determined that this barrier still exists.

\subsubsection{COST OF INSTALLATION AND MAINTENANCE}

The biggest barrier in green roof implementation has been identified as financial cost, including upfront installation costs and maintenance costs. Installation costs for green roofs are generally double that of conventional roofs, however, the lifetime of a green roof is also approximately double that of a conventional roof (Getter \& Rowe, 2006). The cost of installation can vary significantly across regions, depending on type of green roof system, location, labor, equipment used, as well as extra costs associated with disposal, maintenance and operation (Vijayaraghavan, 2016). Ngan (2004) argues that there are various tradeoff's associated with decisions to adopt one type of green roof system over another. While intensive green roofs generally cost more to install and maintain, they also result in higher cost savings over the life span of a green roof system (Ngan, 2004).

Peck et. al. (1999) assert that there is a lack of detailed information about costs, exacerbating problems related to the lack of knowledge regarding benefits of green roofs; especially due to a lack of understanding of direct tangible long-term economic benefits (ibid).

The information that does exist often relays scattered results and are context dependent. Castleton, et. al. (2010) drew data from various projects, consulting firm reports, green roof companies and the Green Roof Centre in the United Kingdom to measure the approximate 
costs associated with the installation of green roofs. They determined that each source reported different ranges of price based on specifications, variants and suggested costs, and ultimately averaged a reasonable cost estimate of $f 150 / m 2$ in 2010 . Bianchini \& Hewage (2012) reported that the 2012 cost of extensive roofs in British Columbia, varied between $\$ 130-\$ 165$ per $\mathrm{m} 2$, while the cost of standard intensive green roof started at around $\$ 540 / \mathrm{m} 2$. Peck \& Kuhn (n.d.) reported the installation costs of extensive roofs as starting from $\$ 215 / \mathrm{m} 2$ and the installation of intensive green roofs at $\$ 323 / \mathrm{m} 2$. The Environmental Protection Agency in the US reported annual maintenance costs of green roofs at approximately $\$ 8 / \mathrm{m} 2$, while acknowledging that these costs could be higher depending on vegetation types, and properties such as planting media and drainage systems used (Environmental Protection Agency, 2017; William, et. al., 2016).

William, et. al. (2016) used simulations and modeling approaches to calculate the life cycle costs of green roofs, cool roofs and conventional roofs in central Illinois, looking specifically at installation, maintenance and energy costs. They found that intensive green roofs resulted in the highest energy savings but highest annual cost, while extensive green roofs had the one of the lowest costs. The cool roof had reduced maintenance and energy costs but highest long-term costs due to frequent need for roof replacements (ibid). Ultimately, they concluded that an extensive green roof would be the most cost effective option in the longterm but noted the lack of consideration towards monetizing other major benefits of green roofs within the study, such as improved air quality and stormwater runoff reductions. Zinzi \& Agnoli (2012) state that modeling green roof simulations can be difficult when using calculation tools because of the number of different variables considered as well as lack of data required. 
While some data exists on installation costs, there is even less information collected regarding maintenance costs and timelines (Binstock, 2011). Maintenance is complex and dependent on the type of green roof installed; generally green roofs require "constant watering, occasional fertilization, regular maintenance checks and weed removal" (Vijayaraghavan, 2016, 748). The extent and frequency of these tasks depend on the type of green roof, plant selection, and climate (ibid). Green roof systems and components are costly to remove or replace, but this can be avoided if green roof system are properly designed and installed (Ngan, 2004). Peck \& Kuhn (n.d.) suggest that maintenance of waterproofing membrane and plants should range from two to three yearly inspections for the removal of weeds and weekly visits for irrigation, pruning and replanting. They assume that maintenance costs range between $\$ 13-\$ 21$ per square metre for extensive green roofs, and $\$ 13.50-\$ 43$ per square metre for intensive green roof. Sproul et. al. (2014) note that maintenance costs for green roofs average \$2.9 US dollars per metre square, while maintenance for cool roofs and conventional roofs are approximately $\$ 0.2$ per metre square annually over a 40 year period. Green roof maintenance costs are also said to be higher in the fist two years Sproul et. al. (2014). Kats and Glassbrook (2015) estimate green roof maintenance costs at $\$ 3-\$ 6.87$ dollars per metre square for the first three years after installation, and $\$ 2.04-\$ 4.61$ meters square past the three year period.

Carter \& Fowler (2008) assert that direct financial incentives can help overcome barriers of adopting green roof technology, especially in the North American context where the industry is not as established. In Toronto, direct incentives are provided through the Eco-roof incentive program for voluntary green roof construction; the program also extends to school boards 
captured by the by-law. The incentive is estimated to cover approximately half of the installation costs associated with green roof construction, however, intensive green roof systems average at a higher cost than this. In addition, no consideration or incentives exists at the city level to address costs associated with maintenance, even though a maintenance plan is required under the Green Roof by-law.

\subsubsection{LACK OF RESEARCH, STANDARDS AND TECHNICAL EXPERTISE}

Generally, there is a lack of research and standards across developing green roof markets in North America (Getter \& Rowe, 2006). In Ontario, the building code's silence on green roof construction caused some Canadian companies to rely on the German FLL guidelines for details on design guidelines and standards for green roofs (Ngan, 2004). This forced the City of Toronto to develop their own standards when it came to green roofs. Although the province is considering such measures now, this comes a full eight years after the City of Toronto already invested in the creation of the Toronto Green Roof Construction Standard (TGRCS), and their supplementary guidelines. The development of these standards was a move in the right direction, and investments to date suggest that this is improving across North America. It is unclear whether a lack of technical expertise and insufficient budgets for green roof projects still act as a barrier in the construction of poor green roof systems leading to negative perceptions of green roof benefits and costs. This also applies to the Lack of expertise around maintenance procedures identified by Peck et. al. (1999); whom stated that this lack of expertise is problematic when improper maintenance leads to roof damage. Suggested solutions to these barriers have been noted as government support for technology diffusion, which the City of Toronto has tried to display through committing to the greening of roofs on 
City owned facilities. Additionally, other measures could include financial support for research on green roofs, potentially partnering with industry leaders to influence government standards or establishing a rating system for companies to "encourage accountability for quality" (Peck et. al., 1999, 53). It is important to note that literature on this issue is dated with respect to the City of Toronto. Further investigation is needed to determine whether or not this barrier is still existent considering the Cities investments in green roof standards, as well as development of the green roof industry since this was examined by literature.

\subsubsection{STRUCTURAL CAPACITY FOR RETROFITS}

Green roof retrofits can be challenging, technically difficult and may be risky to work with due to the increased weight a green roof system would add to an existing roof, potentially compromising structural integrity (Peck et. al., 1999). "Extensive roofs are the preferred option for retrofitting onto existing buildings as the structural capacity of the roof will often not have to be increased" (Castleton, et. al., 2010). Vijayaraghavan (2016) acknowledges that there may be issues such as potential for leaks on green roofs, but asserts that all roofs are susceptible to leakages. He maintains that if properly designed, a green roof can avoid this structural risk (ibid).

Structural assessments of roofs may also be costly, further preventing green roof implementation. A structural analysis conducted by a professional structural engineer is often required to determine the technical viability of green roof installation on existing buildings, by analyzing the load bearing capacity of the existing roof. Lee (2017) states that such an

assessment typically costs up to $\$ 3000.00$. To address this barrier, the City of Toronto 
introduced a Structural Assessment Grant (SAG) in 2016, covering up to $\$ 1000.00$ of the cost of an assessment through the Eco-roof Incentive program.

\subsection{BARRIERS FACED BY TORONTO SCHOOL BOARDS}

In 2016, the City of Toronto retained Lura Consulting to conduct an extensive review of the Eco-roof Incentive Program in order to determine potential changes for improvement, increase program awareness and encourage implementation throughout the City. As part of this review, the firm conducted multiple forms of stakeholder engagement including online surveys, focus groups with roofing professionals and past program participants, and one-to-one interviews. Although the review focused on the City's incentive program, engagement questions directly inquired about the barriers to program participation, green roof implementation and cool-roof implementation. Three major Toronto Public School boards participated in this review: the Toronto Catholic District School Board (TCDSB), the Toronto District School Board (TDSB) and the Toronto French Catholic School Board. (Conseil scolaire de district catholique Centre-Sud). Staff from each School Board was consulted via one-on-one interviews, and some school board representatives were consulted through focus groups held for past participants (although unclear how many constituted this group). Below are synthesized results of barriers that were identified through the interviews.

\subsubsection{MAINTENANCE MANAGEMENT AND COSTS}

All three school boards raised major concerns regarding the cost of on-going maintenance for green roofs. The Toronto District School Board currently faces approximately $\$ 260$ million dollars in maintenance backlogs, which it suspects will take roughly 20 years to address. This backlog includes roof replacements, which are managed on a needs basis. TCDSB 
representatives also noted backlogs in roof replacements, and prioritize such replacements on a needs basis. However, the situation they face is not as severe as that of TDSB. Only TDSB provided an estimate of the annual cost of maintenance for their current inventory of green roofs, which ranges from $\$ 1500$ to $\$ 2000$ per roof. Each school board manages maintenance differently:

1. TDSB - The sustainability team is currently developing a maintenance plan for existing eco-roofs, however details for this are not publicly accessible. Presently, maintenance is provided through an extended warrantee with manufacturers, however no maintenance plan exists past the warrantee expiration.

2. TCDSB - has a roof renewal plan in place, but typically does not consider eco-roofs. They state that insufficient funding results in the inability to outsource maintenance, but do not reveal the current means of maintenance on existing eco-roofs.

3. Toronto French Catholic School Board - Maintenance is usually contracted out, at least for the first year of installation. No details are given for the period succeeding this.

Concerns over the management and cost of maintenance have resulted in the explicit preference for TCDSB and the Toronto French Catholic School Board towards opting out of the Green Roof By-law and instead paying cash-in-lieu of its requirements. For TCDSB and TDSB, a major concern over maintenance is also the roles and responsibilities of staff in management of this task. Both school boards claim that tasks associated with maintenance fall outside the scope of unionized staff responsibilities, and requires further investments for safety training and equipment. The French Catholic board notes that this issue does not pertain to them, as 
they do not have unionized staff. Overall the school boards recommended the following as some potential solutions:

1. More support be directed to offset or assist in ongoing maintenance costs (through grants or reimbursement of at least a portion of costs)

2. More support with identifying qualified contractors for maintenance

3. Providing more information on maintenance procedures and or costs, possibly through case studies

4. Developing a maintenance plan checklist - providing information and reducing time and resources devoted to maintenance plan development

\subsubsection{STRUCTURAL CAPACITY FOR RETROFITS}

Both TDSB and TCDSB raised concerns over the viability of green roof retrofits on aging school infrastructure due to risks associated with structural feasibility of existing buildings. They noted that the extra weight added to roof structures in green roof installations could require substantive design, structural and engineering upgrades that could be costly. School boards in put no recommendations forth on how this issue may be addressed. However, as mentioned previously the City of Toronto supports these additional costs through the allowance of a structural assessment grant (SAG) of up to one third of the estimated costs of a structural assessment. It is also important to note that green roofs are not required on retrofitted buildings. 


\subsubsection{LACK OF AWARENESS OF GREEN ROOF BENEFITS}

Some responses or concerns shared by TDSB made evident that there are still knowledge gaps regarding the benefits of green roofs. As a result, school board staff recommended that a sample business case be given to boards to use in decision-making processes regarding green roof considerations that would provide details of costs and benefits. TDSB staff noted that the only real benefit associated with green roofs is habitat creation, which is not a priority considering associated costs. Staff also noted that eco-roofs provide no visible or tangible benefits. Both TDSB and TCDSB staff revealed preferences to adopt greening measures at grade, such as tree planting or greening playing fields instead of investing in roof improvements, since at grade investments could be correlated with direct benefits for students and staff. While discussing barriers to cool roof implementation, staff noted that not many buildings are air conditioned, resulting in less need for reduced cooling costs associated with cool roofs. Furthermore, they stated that reductions in ambient air temperatures would result in public rather than private benefits, dissuading them from pursuing adoption of this technology.

As explored early in this paper, green roofs do in fact result in a variety of benefits, both public and private. The most pressing value to property owners is the energy saving and reduction in heating and cooling costs. Even though many TDSB buildings might not be equipped with heating and cooling systems, green roofs help to naturally regulate indoor air temperatures, resulting in enhanced thermal comfort. Isaa et. al. (2011) studied different aspects of usage in a sample of conventional, energy-retrofitted and green Toronto Public Schools and compared student, teacher and staff absenteeism data, student performance 
scores, and conducted a survey of teachers to investigate satisfaction related to air quality, lighting, thermal comfort and acoustics of school buildings. They found that teachers in green schools were more satisfied with indoor air quality, heating, ventilation, air conditioning, and thermal comfort (Ibid). They also discovered that absenteeism in green schools improved by 2$7.5 \%$, and student performance improved by $8-19 \%$ in comparison to conventional schools (ibid). Other Studies have shown linkages between greener indoor environments or green buildings in enhancements of student learning, reductions in absenteeism, and productivity improvements (Heschong, 1999; Heschong 2003; Miller et. al., 2009; Milton, et. al. 2000). As our climate continues to change, we face fluctuating air temperatures, more instances of heat waves with greater durations and intensity, resulting in rising heat related deaths (which children are more vulnerable to). In addition, extreme heat days now extend beyond summer months into the Spring and Fall seasons. This suggests that the cooling need for schools will increase. In 2017, the City of Toronto started consultations regarding reducing vulnerability to extreme heat in the community and at home (City of Toronto, 2017d). As a result, the Medical

Officer of Health in Toronto made several recommendations including directing Ontario Building Code updates to mitigate climate change, improve resiliency of buildings, and incorporate passive cooling measures that also minimize energy consumption and GHG emissions from air conditioning (ibid). Green roofs present the opportunity for school boards to deal with the aforementioned issues while meeting the said recommendations.

\subsubsection{LACK OF TECHNICAL GUIDANCE}

The TDCSB and TDSB both suggested through interviews that a list of pre-approved materials for green and cool roofs would be helpful in guiding technical decisions related to the 
construction of eco-roofs. The Toronto Green Roof Construction Standard Supplementary Guidelines do touch upon best practices in construction of green roofs as well as green roof components, definitions, and technical standards. Additionally, The City of Toronto's 2013 Guidelines for Biodiverse Green Roofs provides guidance on recommended plant species, plant species to avoid and other design or material features (City of Toronto, 2013c).

\subsubsection{FUNDING CONCERNS}

The two largest Toronto school boards, TDSB and TCDSB also claimed that a lack of funding coupled with high operating costs in the City of Toronto (15\% higher than the rest of the province) created a barrier to green roof implementation. Although TCDSB argued that the Ministry acknowledges this uplift and as a result provides additional 10 to 15 percent in funding. Nevertheless, both school boards state that the provincial funding model directly impacts their choices regarding green roof adoption. They state that while the City of Toronto provides incentives for installation, these do not cover the entire costs of installation. Hence, they argue that greater financial assistance is necessary to support school boards in the procurement of green roofs.

\subsubsection{SAFETY CONCERNS}

School boards raised issues with managing safety concerns as they relate to green roof access. This includes concerns regarding unauthorized access on school roofs, potentially creating damage to green roof vegetation or cool roof membranes, which will have repercussions for the warrantees in place. Additionally, both TDSB and TCDSB raised apprehensions about having 
to seek working at heights training for staff and volunteer, which would increase costs related to incorporation of green roofs on site.

\subsubsection{ADMINISTRATIVE BURDENS}

The administrative tasks associated with the Eco-roof Incentive Program application submissions were identified as onerous by all school boards. This hinders green roof implementation on school board properties as access to program funding is a large factor in adopting green roofs. TDSB and the Toronto French Catholic School Board also suggested the process be simplified for school boards. TDSB identified a pre-approval process for large landowners would reduce the administrative requirements necessary, and enable a smoother decision-making process for the board. Meanwhile, the French Catholic School Board suggested simplifying the application form itself, through such changes as the introduction of an auto-fill form.

\subsubsection{PARTNERSHIP OPPORTUNITIES}

The TDSB noted having established partnerships with companies in order to reduce costs associated with roof replacements. They partnered with a solar installation company to replace 300 roofs with the conventional roof membrane at a cost of $\$ 10$ per sq. ft., which translates to approximately $\$ 108$ per square metre. Assuming that costs for an extensive green roof range from $\$ 150$ to $\$ 200$, and the City of Toronto provides an incentive of $\$ 100$ per square metre for green roofs, TDSB would likely only be covering the same cost of installation as a conventional roof, when installing an extensive green roof. Additionally, they acknowledge that replacements of conventional (BUR) roofs result in harmful and strong odors due to the use of 
hot asphalt. While the TDSB considered the partnership as advantageous in enabling them to access benefits they otherwise wouldn't be able to afford, the decision to commit to investing in such a system was harmful due to negative externalities on health and environment.

The TCDSB mentioned establishing a partnership with a solar company to install solar panels on approximately half of their schools. The Green Roof By-law allows for the exclusion of roof space dedicated to current or future solar panel installations from the available roof space calculation when determining the amount of green roof required on buildings. Board staff made no mention of understanding this aspect of the regulation. While partnerships might not seem like an evident barrier to green roof implementation, it restricts school boards from seeking other partnerships for potential future green roof investments. Moreover, due to the uncertainty of managing a large volume of green roof contracts, some boards recommended enhanced assistance with the details or requirements of a contract with green roof suppliers. Specifically, with regards to pre-qualification criteria and scope of work required. 


\section{SECTION 3: MOVING FORWARD}

\subsection{INTER GOVERNMENTAL COLLABORATION}

Literature has shown that there is a need for collaborative efforts between municipal, provincial and federal levels of government for the implementation of policy framework guiding municipal action in the green economy (Federation of municipalities, 2011, 2). Evidence suggests that local municipalities are the key entities that can mandate or encourage the use of green roofs as a means to environmental protection goals but that they are not met with adequate support from other levels of government (Carter \& Fowler, 2008; Federation of municipalities, 2011). This section will analyze provincial and federal policies to determine current and potential funding support for green roofs at different levels of government.

\subsection{FEDERAL POLICIES AND FUNDING SOURCES}

In January 2016, the federal government released the Pan-Canadian Framework on Clean Growth and Climate change, which creates the framework for collaboration between the provincial, territorial and federal levels to address climate change and create economic growth. This framework acknowledged that the built environment was the third largest sector in the production of GHG emissions, making up approximately $12 \%$ of all emissions (Government of Canada, 2016). It identified new actions to the built environment, including the development of model building codes in support for more energy efficient buildings through building code changes and retrofits, as 75 percent of the building stock in 2030 will be composed of existing structures (Government of 
Canada, 2016). The federal government also recognized the importance of investment in green infrastructure for the Canadian economy:

Construction in Canada is a \$171 billion industry, and it employs well over a million people. New building codes will spur innovation and support Canadian businesses in developing more efficient building techniques and technologies. Investments in retrofits to improve energy efficiency have been shown to be strong job creators, providing direct local benefits, creating local jobs, and reducing energy bills (Government of Canada, 2016, 15).

They also stated that approximately $\$ 40$ million dollars would be dedicated to the integration of climate adaptation measures in building design guides and codes through updates in the national building code by 2020 (Government of Canada, 2016). Although this framework is useful in outlining a national commitment to climate change resilience and setting examples for provincial and territorial governments, no direct funding has been identified. In their submission to the Pan Canadian Framework on Clean Growth and Climate Change FederalProvincial-Territorial Working Group, Green Infrastructure Ontario (GIO) advocated that living green infrastructure be incorporated into policies, programs, and financial mechanisms of efforts to address climate change. (Green Infrastructure Ontario, n.d.). The report outlined five specific recommendations, including implementation of living infrastructure in policy backed by a commitment from all levels of government to allocate at least $15 \%$ of infrastructure funding to living green infrastructure investment. They also recommended that a life-cycle management approach be applied to infrastructure projects, and identified the need for a dedicated fund. None of these recommendations were realized in the Pan Canadian Framework on Clean Growth and Climate Change upon release. 
However, federal funding for green infrastructure investments is available through the Federation of Canadian Municipalities' (FCM) Green Municipal Fund (GMF) (Coutinho, 2016). The federal governments 2016 capital budget, proposed $\$ 125$ million over two years to the FCM to enhance the GMF, specifically for projects that reduce GHG emissions and provide tangible community benefits through environmental, social and economic outcomes (Infrastructure Canada, 2017). Since its inception in 2000, GMF has financed over $\$ 700$ million to municipal green infrastructure projects (Infrastructure Canada, 2017). However, this funding is traditionally dedicated to large singular municipal projects, such as the solar city in Halifax and does not have any portion of funding dedicated to living green infrastructure (Infrastructure Canada, 2017). Federal policies could have a larger role in environmental protection and provide direct green roof funding by means of grants or subsidization through tax relief for green roof installations (Carter \& Fowler, 2008).

\subsection{PROVINCIAL POLICIES AND FUNDING SOURCES}

The province of Ontario released its Climate Change Strategy in 2016. Policies outlined in provincial documents are more relevant to the subject at hand as education is a provincial responsibility. This strategy outlined the need for public sector reductions in carbon emissions, including municipalities, hospitals, schools and universities. Much like the federal climate change policy, the province identified built form as a large contributor to GHG emissions; stating that they are the third largest sector representing approximately $19 \%-24 \%$ of overall emissions. The province also recognized the economic benefits that climate-related technologies such as green roofs create; citing that $\$ 100$ million invested in these technologies 
generates \$107 million in GDP and results in 1400 new jobs (Ministry of the Environment and Climate Change, 2016a, 17).

Within the same year, the province also released Ontario's Five-Year Climate Action Plan 2016 - 2020. The action plan aims to create actions to realize the goals outlined within the Climate Change Strategy, and to create awareness, jobs and growth in the green economy. Action areas identified included: transportation, buildings and homes, land-use Planning, industry and business, collaboration with Indigenous communities, research and development, government, and agriculture, forests and lands. Specific actions in the buildings and homes sector included improving energy efficiency in schools and hospitals (Ministry of the Environment and Climate Change, 2016b, 26). The province outlined intentions to provide funding for existing schools to improve energy efficiency and for the installation of renewable energy technologies - however, green roofs were not explicitly mentioned. Another action identified in this sector included setting lower carbon standards for new buildings through updates to the provincial building code targeting new net zero carbon emissions and long-term energy efficiency. Actions within land-use planning included strengthening climate change policies by setting green development standards so that municipalities would be able to pass by-laws in areas outside of new construction. Additionally, the province outlined amending the Municipal Act and City of Toronto Act to enable municipality's province-wide require standards or technologies to reduce emissions, where technical building code standards exist. Finally, the plan outlines support for municipal and stakeholder climate action through fostering partnerships with organizations, private sector and institutions such as schools to find new ways to lower-carbon and deliver initiatives. 
Ontario plans on financing actions in its climate change plan through establishing a Green Bank and the Green Ontario Fund. All three will be receive funds from proceeds of Ontario's Cap and Trade program for carbon emissions, which will be held in the Greenhouse Gas Reduction Account (GGRA). In February 2016, the provinces' Climate Change Mitigation and Low-Carbon Economy Act, (Bill 172) received Royal Assent - requiring all proceeds from Ontario's cap and trade program be invested back into projects that reduce greenhouse gas pollution (Ministry of the Environment and Climate Change, 2016c). This figure is estimated at approximately $\$ 1.9$ billion dollars annually (Ministry of the Environment and Climate Change, 2016c). The Green Bank provides information and financial support for homeowners and businesses to better access energy-efficient technologies, and supports commercial and industrial projects are also outlined for projects that "require scale to be financed privately, by working with commercial banks to help aggregate projects to reduce risk" (Ministry of the Environment and Climate Change, 2016d, 17). The Green Bank has no funds allocated to institutions. The Green Ontario Fund was established with $\$ 377$ million dollars worth of Cap and trade proceeds and is a new non-for profit agency that will deliver programming and rebates for homeowners, businesses, and large industry (ibid). This arose out of the Green Investment Fund, which saw an initial \$325 million dollars from the province’s down payment on the cap and trade program (ibid). Although the province is dedicating significant amounts of funding from the cap and trade proceeds back into reducing GHG emissions and even though they outlined reductions for public schools as essential in their strategy, none of the funds established are actually applicable for aiding school boards fund green infrastructure projects or energy efficiency measures in new builds and retrofits. 
Hence, school boards in Ontario have no direct funding sources to allocate for green infrastructure investment at the provincial level. However, the Ministry of Education does fund capital funding for new school as well as additions and renovations. The Ministry of Education (2017a) estimates that the province has provided close to $\$ 17.5$ billion dollars in capital funding to school boards for more than 820 new schools and more than 800 additions and renovations since 2003; and is projected to provide close to $\$ 16$ billion over the next 10 years (Ministry of Education, 2017b). These investments not only go towards new builds and improvements in existing buildings but also towards projects to reduce surplus space, such as school consolidations (Ministry of Education, 2017b). However, Toronto school boards such as the Toronto Districts School Board (TDSB) and the Toronto Catholic District School Board (TCDSB) maintain that the capital funding is not enough to cover maintenance backlogs estimated at $\$ 3.5$ billion for TDSB and $\$ 600$ million for TCDSB (Rushowy, 2016). In 2016, the province increased funding for both boards, giving TDSB $\$ 579$ million and TCDSB a total of $\$ 107$ million (Rushowy, 2016). However, due to the deteriorating conditions of schools, half of which are over 40 years old, the funds are still not enough. This results in no funding left over for boards to invest in green infrastructure and explains the hesitation and lack of ability to place funds aside for green roof construction and maintenance as mandated by the City of Toronto.

\subsection{POTENTIAL MUNICIPAL FUNDING SOURCES}

Lee (2017) recommends that City of Toronto incur additional financial responsibility to provide several incentives, rather than depending only on the direct financial incentive with cash-in-lieu contributions. She asserts that the incorporation of green roofs as a stormwater management incentive would make for a better option and suggests that stormwater runoff 
charges may be the answer (Lee, 2017). Toronto Water announced plans for a stormwater fee in 2015, to take effect in 2018 and would raise funds to pay for capital projects that would deal with the stormwater management system (Cross, 2015). This fee is progressive as it bases the fee on the amount of impervious surface within a property, thus charging those who contribute to stormwater management issues more than others (Coutinho, 2016; Li, 2013). Schools are typically larger buildings, with vast amounts of pavement and larger roof spaces, meaning that such a charge may dissuade them from forgoing green roof installations (Coutinho, 2016). Unfortunately, the City of Toronto opted not to implement a stormwater impact fee and Mayor John Tory stated that the idea would be shelved until 2019 (Rider, 2017). Additionally, during the consideration period the City was contemplating whether school boards would be exempt from this fee. Toronto can look to many regions that have implemented the fee, such as the District of Columbia, in the United States. The District of Columbia Department of the Environment (DDOE) collects "a stormwater impact fee on commercial and residential properties based on amount of impervious surface and puts the funds towards managing stormwater pollution in the district" $(\mathrm{Li}, 2013,22)$. The City of Washington in the District of Columbia has used this as an opportunity to further incentivize stormwater management practices by provides an additional stormwater discount fee based on area of impervious surface on a property, when it is reduced (Li, 2013, 24).

Alternatively, the City of Toronto also has the option of redistributing or developing further incentives from funds located in the Eco-Roof Financial Assistance Reserve Fund. The City reported that as of January $26^{\text {th }}, 2017$, there was $\$ 2,220,177.17$ in the Eco-Roof Financial Assistance Reserve Fund (City of Toronto, 2017e). This amount of funds available due to cash- 
in-lieu contributions represents approximately 11,100 square metres of green roof not built within the City. This presents an opportunity to dedicate some portion of these funds to additional incentives to help green roof implementation. 


\subsection{DISCUSSION}

The barriers that Toronto School boards face in the implementation of green roofs across new and existing properties are not minimal. The reasons behind school board decisions to opt out of providing a green roof, as explored through an analysis of cash-in-lieu documentation and interview results with three prominent school boards, suggests that there is much to be done. While the City of Toronto took steps to reduce these barriers - through taking early steps to identify them in the policy development process, expanding eco-roof program funding to schools, and developing a structural adjustment grant- municipal measures alone have proven to be insufficient in easing school board concerns.

It is clear that more support is needed from the Provincial and Federal Governments. It has been 12 years since the City of Toronto initiated support for green roofs through the Green roof strategy and 8 years since they established regulation and standards to encourage green roof construction. Yet, it seems that general barriers identified through literature are still prevalent today. This goes to show the challenges in adopting mitigation and adaptation strategies, without collaboration from all levels of government. While there are still measures available to the City of Toronto, it is time for the provincial and federal government to step up. Especially, the province since it is responsible for education funding. While discussions around updates to the 2019 Ontario Building Code prove to be hopeful, providing the choice to implement green roofs will be unfruitful unless the necessary funding accompanies changes in policy. 
School boards have been asking the province for more support regarding green roof implementation since inception of the by-law, twice with the support of the City of Toronto through Council recommendations. In fact in 2016, the City of Toronto City-School Boards Advisory Committee and City Council, recommended that the Government of Ontario align capital and operating budget allowances with their own Ontario Climate Change Strategy and Action Plan, in order to support school boards in meeting requirements under the Green Roof By-law and under the Toronto Green Standard (Toronto City-School Boards Advisory Committee, 2016). On a provincial level, it is clear that climate change policies have identified a need and goal for funding to be allocated to schools in order to increase energy efficiency, reduce GHG emissions and to achieve other benefits. However, current funding through the Green Bank and the Green Ontario Fund does not allocate any provisions for schools to receive additional funding.

School boards have a right to demand more from the province, as they are the authority dealing with a mass inventory of aging infrastructure and a growing list of maintenance backlogs. The province needs to be mindful of the fact that not taking steps to help school boards means that public funds are being directed towards private benefits, as the funds are then used to support other private projects through the Eco-Roof Incentive program. Toronto School Boards also need to recognize that investing in their properties through traditional grey infrastructure, such as roof replacements with conventional systems, only perpetuates the cycle of issues that they face.

The federal government has a smaller role to play with respect to funding for schools; however, they have responsibilities for leading climate change adaptation and mitigation. With 
that said, the Federal government needs to more specifically acknowledge the benefits of living green infrastructure and bring awareness to its benefits. It is unclear what support future building codes will have for green roofs but funding support through grants or subsidization through tax relief for green roof installations is an option.

The City also needs to focus on addressing concerns communicated by school boards. The City's success with green roof implementation on schools is still hindered by many of the initial barriers identified through policy development. As shown through quantitative analysis, almost half of school site plans have been captured by the green roof by-law (from Jan 2010 to Oct 2017), and approximately half all schools caught by the by-law chose to provide cash-in-lieu of a green roof. This necessitates action on the part of the municipality to strive for continuous evaluation and improvement to address concerns. In fact, school boards have identified particular measures that may alleviate pressures through the Eco-roof Incentive Program Review. These suggestions attempted to breakdown obstacles to funding concerns, maintenance management and costs, reduce uncertainty and lack of awareness, reduce administrative barriers and improve access to information regarding green roofs to enable enhanced decision making processes. While some recommendations may be outside the scope of the City's influence, many can be directly addressed.

With respect to maintenance, it is clear that more information is needed for school boards to make effective decisions regarding green roof installations. They have clearly identified that they do not quite understand the necessary costs to expect, and need direction on maintenance procedures and costs. While they have experience with green roofs on some existing buildings, School boards have struggled with maintaining the roofs once warrantee or 
maintenance plans with installation companies have subsided. Based on prior experiences managing maintenance of current roofing features and the uncertainty of costs related green roof maintenance, school boards have been hesitant in accepting this responsibility. They lack the connections to contractors and are uncertain about how to identify qualified companies. They also have little information on what a green roof should cost and what is typical to ask of green roof companies in terms of maintenance agreements. This uncertainty feeds the perception that school boards may not always be getting the best deal when seeking out qualified contractors. The concerns relating to maintenance being outside the scope of unionized staff, and requiring extra costs associated with safety training are valid. However, this issue is one that is internal to school management. It may be addressed as school boards gain a stronger understanding of what maintenance activities are required for ongoing upkeep of green roofs. Their proposal for being provided with a maintenance plan checklist also seems to aid in reducing this barrier. While some installation companies provide clients with this resource, not all companies do. It would be wise to have a standard maintenance plan checklist for schools catered to each type of green roof.

With respect to addressing the issue of structural capacity, school boards need to be more informed on the options existent for retrofits. For example, the NYC Department of Education Office of Sustainability, School Construction Authority, and Department of Environmental Protection Office of Green Infrastructure came together to create such a resource for New York City schools. They authored and released A Guide to Green Roofs on Existing School Buildings, relaying information on: the types of green roofs available, benefits of green roofs, educational opportunities, planning requirements and considerations including 
upfront costs to expect, what to look for in existing roof conditions, structural loading capacity, on going maintenance costs to expect, and requirements to meet (NYC Department of Education Office of Sustainability et. al., n.d.). Such a guide addressed issues of uncertainty with requirements while also providing much needed information to school boards regarding decisions to install a green roof. This guide could also incorporate case studies specific to school buildings or properties that displays the range of options for design, materials and more. Concerns around safety could potentially be addressed through the aforementioned option as well. School boards raised concerns about unauthorized access to the roof and potential vegetation damage as a result of this. Case studies displaying how other school properties have dealt with concerns over safety could notify school boards on design options that could mitigate this risk. Unfortunately, due to time constraints and ethical considerations, such data could not be collected within this study.

It is noted that the City intentionally developed green roof standards and regulation to allow flexibility in design; however, schools need specific information on the interpretation of such standards. Whilst developers, engineers, roofing companies, and other professionals might be able to understand such details, school board staff need additional assistance. While the City took early measures to provide information sessions for stakeholders such as school boards, it would be wise to continue with regular sessions to ensure that updates, amendments and other changes are fully understood. This would also enable opportunities for continuous consultation that could influence improvements to ensure success.

School boards also identified administrative burdens with applications to partake in the Eco-roof Incentive Program. This is problematic as access to this funding is essential to cover 
installation costs and in order to qualify for structural assessment grants. The Eco-roof Incentive Program Review recommended that the application form be made easier through the introduction of auto-fill sections. The school boards recommended that that a pre-approval process for large landowners would enable better means for a smooth decision-making process, as school boards would not need wait for approval of funding. This study echoes the suggestion of the school boards, acknowledging that public schools are a unique category of participant as they provide community spaces and benefits, and are essentially privately managed public structures.

Finally, school board noted that current partnerships with companies for roof replacements have proven beneficial in allowing them to secure more affordable prices for such improvements. School boards need to recognize that such partnerships can also be formed with green roofing companies. School boards have the ability to leverage partnerships due to the significant portion of properties that they own within the City. They stated that they would also need assistance with managing a large volume of green roof contracts with green roof suppliers. However, by establishing a partnership with one company, the board would likely reduce costs and only need to manage one comprehensive contract, thus reducing administrative burdens. Options to explore for attaining such a contract could be a request for proposals by school boards. 


\subsection{RECOMMENDATIONS}

Based on the findings of this study and aforementioned discussion, the following recommendations have been made:

\subsection{FEDERAL ACTION}

1. It is recommended that the federal government explore options for grants or subsidization through tax relief for green roof installations (Carter \& Fowler, 2008)

\subsection{PROVINCIAL ACTION}

1. It is recommended that the province expand programs through the Green Ontario fund to capture new and existing school projects, including projects for green roofs.

2. The province mandate that a portion of the capital investment funds that school boards receive be strictly dedicated to green infrastructure, including green roofs.

3. The province should align school capital and operating budgets to support the 2016 Climate Change Action Plan, as well as aid schools in adhering to the Green Roof by-law and green standards.

\subsection{MUNICIPAL ACTION}

1. It is recommended that the City develop a Green roof guide for Toronto school boards, equipped with information on types of green roofs available, benefits of green roofs, educational opportunities, planning requirements and considerations including upfront costs, what to look for in existing roof conditions, structural loading capacity, on going maintenance, and requirements to meet. 
2. It is recommended that the City of Toronto form partnerships with Toronto Public School Boards, pre-approving public schools for the Eco-roof Incentive program in order to decrease administrative burdens associated with the application.

3. Should funds exist, the City should create a direct incentive to cover a portion of maintenance costs for schools and non-for-profits. The City should be aware that maintenance is usually covered under warrantee for the first two to three years after installation, and no precedent examples have been found to include cover the costs of maintenance.

4. It is recommended that the City of Toronto adopt a stormwater fee or stormwater tax. The latter could provide tax breaks for those who take measures to reduce the amount of stormwater runoff within their properties.

5. It is recommended that the City of Toronto host regular information sessions with property owners (including school boards) to provide more information on standards, requirements, and regulation. This is also a good opportunity for the City hear and understand concerns related to such regulation, in order to inform future improvements.

\subsection{TORONTO PUBLIC SCHOOL BOARDS}

1. To address a lack of uncertainty regarding maintenance costs, it is recommended that Toronto School Boards seek estimates from private companies.

2. It is recommended that Toronto Public School Boards seek future partnerships with Green Roof Suppliers. 
3. It is recommended that Toronto Public School Boards invest in development of maintenance plans for green roofs, or request that green roof suppliers provide a maintenance checklist with installation.

4. It is recommended that Toronto Public School Boards consider reevaluating decisions to provide CIL considering that payments are made from Capital budgets, when providing a green roof could in fact reduce operational costs associated with heating and cooling. The opportunities lost with this payment are often substantial.

\subsection{FUTURE RESEARCH}

1. Further research should be conducted to compile case studies of green roofs on existing school buildings, to ascertain how schools may have addressed safety concerns in design, educational programs, and how schools may have overcome some general or similar barriers.

2. Future research should look to conduct a cost-benefit analysis of green roofs on institutional buildings; specifically school buildings to better equip school boards with information regarding green roof investments.

3. More research needs to be conducted to account for the triple bottom line of green roofs, incorporating considerations towards the qualitative benefits that they provide.

4. It is recommended that more research be conducted to gain data on maintenance costs associated with green roofs, across various building structures and green roof types. 


\subsection{CONCLUSION}

The public and private benefits that green roofs can provide have been well documented. Green roofs provide immense environmental advantages that result in positive public health outcomes, and represent an important component of broader green infrastructure measures to combat the impacts of climate change. They also create social gathering spaces, increase access to green space within urban areas and offer an important educational opportunity to inform younger generations of the importance of environmental sustainability. These benefits have not gone unnoticed by the federal, provincial, and municipal governments. While the federal government is making steps to become a leader in climate change resilience and adaptation, they are not the best positioned for delivering on the ground changes. When it comes to Toronto School boards, it can be determined that the larger responsibility rests on the shoulders of the provincial and municipal governments. In the wake of barriers such as uncertainty, lack of awareness and large maintenance backlogs, Toronto Public Schools need more support and guidance in order to make secure investments for green roof incorporation across their properties. This study attempted to identify the barriers associated with green roof implementation across Toronto Public Schools in order to suggest options moving forward to overcome such barriers. This was done to also inform the adoption of green roof legislation and incentives in other Ontario municipalities, as the province considers expanding their ability implement such regulation. However, it should be noted that schools operating in the City of Toronto generally face more funding constraints due to high operation costs. Nevertheless, the barriers they face shed light on the potential barriers that 
schools in other regions could struggle with, should legislation be enforced. Regardless, improvements made in Toronto's case can act as a model for other municipalities, such as the need for continuous information sessions and access to resources for green roof implementation. 
12.0 APPENDIX

\begin{tabular}{|c|c|c|c|}
\hline \multicolumn{4}{|c|}{ Synthesized School Board Green-Roof By-law Exemption Report Details } \\
\hline Application & $\begin{array}{l}\text { Type of } \\
\text { Exemption } \\
\text { Sought }\end{array}$ & $\begin{array}{l}\text { Payment } \\
\text { required }\end{array}$ & Rationale \\
\hline 1 & Complete & $\$ 74,000$ & $\begin{array}{l}\text { a. Cool roof are a more cost-effective } \\
\text { option that comply with the Toronto } \\
\text { Green Standard requirements } \\
\text { b. Maintenance program is unfunded and } \\
\text { cannot be justified amongst competing } \\
\text { annual budget demands } \\
\text { c. Lack of funding from the Ministry of } \\
\text { education to cover installation and } \\
\text { maintenance } \\
\text { d. Other measures are being taken to } \\
\text { produce environmental benefits, i.e. } \\
\text { tree planting } \\
\text { e. Green roofs are negligible as a teaching } \\
\text { opportunity; rather allocate funding to } \\
\text { improve sites at grade }\end{array}$ \\
\hline 2 & Complete & $\$ 66,080.00$ & \begin{tabular}{|l} 
a. $32-39$ kw photovoltaic system (solar \\
panels) are planned covering $320 \mathrm{~m} 2$ of \\
roof space \\
b. Configuration of the roof results in \\
fragmented design of potential green \\
roof, reducing perceived \\
environmental value and raising the \\
difficulty of maintenance
\end{tabular} \\
\hline 3 & Complete & $\$ 64,368.00$ & \begin{tabular}{|l} 
c. $32-39$ kw photovoltaic system (solar \\
panels) are planned covering $320 \mathrm{~m} 2$ of \\
roof space \\
d. Configuration of the roof results in \\
fragmented design of potential green \\
roof, reducing perceived \\
environmental value and raising the \\
difficulty of maintenance
\end{tabular} \\
\hline 4 & $\begin{array}{l}\text { Complete (cool } \\
\text { roof sought } \\
\text { instead - however } \\
\text { application was } \\
\text { prior to } 2012 \text { so } \\
\text { CIL payment } \\
\text { made) }\end{array}$ & $\$ 92,160.00$ & $\begin{array}{l}\text { a. Cool roof are a more cost-effective } \\
\text { option that comply with the Toronto } \\
\text { Green Standard requirements } \\
\text { b. Maintenance program is unfunded and } \\
\text { cannot be justified amongst competing } \\
\text { annual budget demands } \\
\text { c. Lack of funding from the Ministry of } \\
\text { education to cover installation and } \\
\text { maintenance } \\
\text { d. Other measures are being taken to }\end{array}$ \\
\hline
\end{tabular}




\begin{tabular}{|c|c|c|c|}
\hline & & & $\begin{array}{l}\text { produce environmental benefits, i.e. } \\
\text { tree planting } \\
\text { e. Green roofs are negligible as a teaching } \\
\text { opportunity; rather allocate funding to } \\
\text { improve sites at grade }\end{array}$ \\
\hline 5 & $\begin{array}{l}\text { Partial ( } 28 \% \text { of } \\
\text { requirement is } \\
\text { proposed) }\end{array}$ & $\$ 148,000.00$ & $\begin{array}{l}\text { a. } \\
\text { opplicant pursuing rooftop parking } \\
\text { on no other feasible space exists } \\
\text { on site } \\
\text { b. A rooftop playground is also planned } \\
\text { c. Other green features are adopted, i.e. } \\
\text { rainwater harvesting for use in toilets } \\
\text { (LEED Silver pursued) }\end{array}$ \\
\hline 6 & Complete & $\$ 132,600.00$ & No reason outlined \\
\hline 7 & $\begin{array}{l}\text { Partial ( } 44 \% \text { of } \\
\text { requirement is } \\
\text { proposed) }\end{array}$ & $\$ 275,300.00$ & $\begin{array}{l}\text { a. Other environmental measures are } \\
\text { incorporated, i.e. high efficiency } \\
\text { heating and cooling } \\
\text { b. Cool roof pursued instead } \\
\text { c. Limited funding by the Ministry of } \\
\text { Education for capital costs and } \\
\text { maintenance } \\
\text { d. Will utilize eco-roof incentive but due } \\
\text { to lack of maintenance coverage } \\
\text { cannot provide full requirement } \\
\text { e. Green roof area provided will be } \\
\text { accessible and used as part of a food } \\
\text { share urban farm program as well as } \\
\text { for educational use }\end{array}$ \\
\hline 8 & Complete & $\$ 179,800.00$ & $\begin{array}{l}\text { Lack of funding from the Ministry of } \\
\text { education }\end{array}$ \\
\hline 9 & Complete & $\$ 65,600$ & No reason outlined \\
\hline 10 & $\begin{array}{l}\text { Partial ( } 4 \% \text { of } \\
\text { requirement is } \\
\text { proposed) }\end{array}$ & $\$ 275,748.00$ & No Reason Outlined \\
\hline 11 & Complete & $\$ 30,640.00$ & $\begin{array}{l}\text { a. Lack of structural capacity on roof to } \\
\text { support an addition as well as a green } \\
\text { roof } \\
\text { b. Solar panels planned for roof } \\
\text { c. Area remaining will be used for } \\
\text { mechanical equipment } \\
\text { d. Other environmental initiatives } \\
\text { pursued, i.e. permeable sod area on } \\
\text { ground level }\end{array}$ \\
\hline 12 & Complete & $\$ 70,200.00$ & $\begin{array}{l}\text { a. Maintenance costs are too high } \\
\text { b. Solar panels already cover existing } \\
\text { building }\end{array}$ \\
\hline
\end{tabular}




\subsection{REFERENCES}

Adger, W. N., Dessai, S., Goulden, M., Hulme, M., Lorenzoni, I., Nelson, D. R., Naess, L. O., Wolf, J. \& Wreford, A. (2009) Are there social limits to adaptation to climate change? Climatic Change, 93(3-4), pp. 335-354.

Alcoba, N. (2011, November 8). City May Ease Green Roof Rules on New Buildings. National Post. Retrieved from http://nationalpost.com/posted-toronto/city-may-ease-green-roofrules-on-new-buildings

Banting, D., Doshi, H., Li, J., Missios, P., Au, A., Currie, B. A., Verrati, M. (2005). Report On The Environmental Benefits And Costs Of Green Roof Technology For The City Of Toronto. Prepared By Ryerson University For The City of Toronto. Retrieved from http://www.toronto.ca/greenroofs/findings.htm

Baynton, A., \& D’Souza L. A. (2016). City of Toronto: Eco-Roof Incentive Program Review. Lura Consulting; The Cardinal Group Inc.

Bianchini, F, Hewage K. (2012). How “Green” Are Green Roofs? Lifecycle Analysis of Green Roof Materials. Building and Environment, 48, page 57-65.

Binstock, M. (2011). Greening Stormwater Management in Ontario: An Analysis of Challenges and Opportunities. Canadian Institute for Environmental Law and Policy. www.cielap.org

Carter, T., \& Fowler, L. (2008). Establishing Green Roof Infrastructure Through Environmental Policy Instruments. Environmental Management, 42(151-164).

Castleton, H. F., Stovin, V ., Beck, S. B. M. \& Davidson, J. B. (2010). Green Roofs; Building Energy Savings and The Potential For Retrofit. Energy and Buildings, 42, pg. 1582-1591. 
City of Toronto. (n.d.[a]). Green Roof Overview. Retrieved from https://www.toronto.ca/citygovernment/planning-development/official-plan-guidelines/green-roofs/green-roofoverview/

City of Toronto. (n.d.[b]). Toronto At a Glance. Retrieved from https://www.toronto.ca/citygovernment/data-research-maps/toronto-at-a-glance/

City of Toronto Act, 2006, SO 2006, chapter 11, Schedule A. Retrieved from https://www.ontario.ca/laws/statute/06c11\#BK138

City of Toronto. (2006). Making Green Roofs Happen. Retrieved from https://www.toronto.ca/legdocs/2006/agendas/council/cc060131/pof1rpt/cl020.pdf

City of Toronto. (2007a). Requiring and Governing the Construction of Green Roofs in Toronto. Retrieved from https://www.toronto.ca/legdocs/mmis/2007/pg/bgrd/backgroundfile4973.pdf

City of Toronto. (2007b). Change is in the Air: Toronto's Commitment to an Environmentally Sustainable Future. Retrieved from https://www.toronto.ca/legdocs/mmis/2007/ex/bgrd/backgroundfile-2428.pdf

City of Toronto. (2008a). Update on Green Roof Strategy. Retrieved from http://app.toronto.ca/tmmis/findAgendaltem.do

City of Toronto. (2008b). Eco-Roof Incentive Program. Retrieved from https://www.toronto.ca/legdocs/mmis/2008/pg/bgrd/backgroundfile-16869.pdf

City of Toronto. (2008c). By-Law to Require and Govern the Construction of Green Roofs in Toronto. City Council Consideration. Retrieved from http://app.toronto.ca/tmmis/viewAgendaltemHistory.do?item=2008.PG20.7 
City of Toronto. (2009a). By-Law to Require and Govern the Construction of Green Roofs in Toronto. Retrieved from http://app.toronto.ca/tmmis/viewAgendaltemHistory.do?item=2009.PG24.2

City of Toronto. (2009b). By-law to Require and Govern the Construction of Green Roofs in Toronto. Retrieved from http://app.toronto.ca/tmmis/viewAgendaltemHistory.do?item=2009.PG25.3

City of Toronto. (2009c). Supplementary report: Green Roof By-law Communications. Retrieved from https://www.toronto.ca/legdocs/mmis/2009/pg/bgrd/backgroundfile-20605.pdf

City of Toronto. (2010). Update and Revisions to the Eco-Roof Incentive Program. Retrieved from http://app.toronto.ca/tmmis/viewAgendaltemHistory.do?item=2010.EX40.7

City of Toronto. (2012a). Amendment to the Green Roof Bylaw for Public and Separate School Board Buildings. (Reference No. Pg12017). Retrieved from https://www.toronto.ca/legdocs/mmis/2012/pg/bgrd/backgroundfile-45778.pdf

City of Toronto. (2012b). Eco-Roof Incentive Program: Creation of Reserve Fund. Retrieved from http://app.toronto.ca/tmmis/viewAgendaltemHistory.do?item=2012.PG13.3

City of Toronto. (2013a). Toronto Municipal Code Chapter 492, Green Roofs. Retrieved from https://www.toronto.ca/legdocs/municode/1184_492.pdf

City of Toronto. (2013b). Eco-Roof Incentive Program: Progress Report \#3. Retrieved from http://app.toronto.ca/tmmis/viewAgendaltemHistory.do?item=2013.PG25.17

City of Toronto. (2013c). Guidelines for Biodiverse Green Roofs. Retrieved from https://web.toronto.ca/wp-content/uploads/2017/08/8d24-City-of-Toronto-Guidelinesfor- Biodiverse-Green-Roofs.pdf

City of Toronto. (2016). Eco-Roof Incentive Program Review and Update. Retrieved from http://app.toronto.ca/tmmis/viewAgendaltemHistory.do?item=2016.PG16.4 
City of Toronto. (2017a). 2016 Census: Population and Dwelling Counts. Retrieved November 15, 2017 from https://www.toronto.ca/wp-content/uploads/2017/10/96b9-2016-CensusBackgrounder-Population-Dwellings.pdf

City of Toronto. (2017b). How Does the City Grow? Retrieved January 9, 2018 from https://www.toronto.ca/wp-content/uploads/2017/10/9773-How-Does-the-City-GrowApril-2017.pdf

City of Toronto. (2017c). Toronto Green Roof Construction Standard Supplementary Guidelines. Retrieved from https://www.toronto.ca/wp-content/uploads/2017/08/7eb7-TorontoGreen-Roof-Construction-Standard-Supplementary-Guidelines.pdf

City of Toronto. (2017d). Reducing Vulnerability to Extreme Heat in the Community and at Home. Retrieved from https://www.toronto.ca/legdocs/mmis/2017/hl/bgrd/backgroundfile-103572.pdf

City of Toronto. (2017e). Eco-Roof Incentive Program Application. Retrieved from https://www.toronto.ca/legdocs/mmis/2017/pg/bgrd/backgroundfile-100927.pdf

Coutinho, W. S. (2016). Stormwater Management: Municipal Policies in Ontario for Managing Rain Where it falls Through Green Infrastructure. Master of Planning Thesis. Ryerson University; Toronto, ON.

Cross, J. S. (2015, December 13). New Stormwater Charge Coming to Toronto. Toronto Metro. Retrieved from http://www.metronews.ca/news/toronto/2015/12/13/new-stormwatercharges-coming-to-toronto.html

Currie, B. A. \& Bass, B. (2010). Using Green Roofs to Enhance Biodiversity in the City of Toronto. Discussion Paper Prepared for Toronto City Planning. Retrieved from https://web.toronto.ca/wp-content/uploads/2017/08/8d71-Using-Green-Roofs-toenhance-Biodiversity-in-the-City-of-Toronto.pdf 
Federation of Canadian Municipalities. (2011). Building Canada's Green Economy: The Municipal Role. Retrieved from http://institute.smartprosperity.ca/sites/default/files/publications/files/Building\%20Cana da\%27s\%20Green\%20Economy.pdf

Forbes, D. J. (2010). An Analysis of Municipal Tools for Promoting Green Roof Technology into Dense Urban Development. Thesis, Tufts University.

Foster, J., Lowe, A., \& Winkelman, S. . (2011). The Value of Green Infrastructure for Urban Climate Adaptation. The Center for Clean Air Policy. Retrieved from www.ccap.org.

Franko, M. (2012). Schoolyard Parks: How the Establishment of a Formal Partnership between the Toronto District School Board and The City of Toronto to Green Schoolyards Can Increase Access to Public Park Space Across the City. Master of planning, Queens University

Getter, K. L., \& Rowe, B. (2006). The Role of Extensive Green Roofs in Sustainable Development. HortScience, 41(5), pp. 1276-1285.

Gifford, R. (2011) The dragons of inaction: Psychological barriers that limit climate change mitigation and adaptation, American Psychologist, 66(4), pp. 290-302.

Government of Canada. (2016, January 25th). The Pan-Canadian Framework on Clean Growth and Climate Change: Canada's Plan to Address Climate Change and Grow the Economy. Retrieved from https://www.canada.ca/content/dam/themes/environment/documents/weather1/20170 113-1-en.pdf

Green Infrastructure Ontario Coalition. (n.d.) The Role of Green Infrastructure in Climate Change Adaptation and Resilience: A submission to the federal/provincial/territorial working group on adaptation and climate resilience for the Pan Canadian Framework on Clean Growth and Climate Change. Retrieved from 
http://greeninfrastructureontario.org/wp-content/uploads/2016/10/GIOs-Comments-onthe-Federal-Pan-Canadian-Climate-Change-Framework.pdf

Halsall Associates Limited. (June 20, 2007). Green "Vegetative" Roof Building Standard for the City of Toronto. Retrieved from https://www.toronto.ca/legdocs/mmis/2007/pg/bgrd/backgroundfile-5165.pdf

Heschong, L. (1999). Daylighting in schools: an investigation into the relationship between daylighting and human performance. California Energy Commission.

Heschong, L. (2003). Windows and classrooms: a study of student performance and the indoor environment. California Energy Commission.

Infrastructure Canada. (2017, April 5). Investing in Green Infrastructure. Retrieved from http://www.infrastructure.gc.ca/plan/gi-iv-eng.html

Issa, M. H., Rankin, J. H., Attalla,, M., \& Christian, A. J. (2011). Absenteeism, Performance and Occupant Satisfaction with the Indoor Environment of Green Toronto Schools. Indoor and Built Environment, 20(5), p. 511-523.

Kats, G., \& Glassbrook, K. (2015). Washington, DC Smart Roof Cost-Benefit Report. Capital E. Retrieved from http://cap-e.com/wpcontent/uploads/2015/04/DC_SmartRoofReport_2015-04-16.pdf

Kim, J., Hong, T., \& Koo, C. W. (2012). Economic and Environmental Evaluation Model for Selecting the Optimum Design of Green Roof Systems in Elementary Schools. Environmental Science Technology, 46, pp. 8475-8483.

Kudryavtev, A., Krasny, M. E., \& Stedman, R. C. (2012). The impact of environmental education on sense of place among urban youth. Ecosphere, 3(4).

Lawlor, G., Currie, B. A., Doshi, H., Wieditz, I. (2006). Green Roofs: A Resource Manual for Municipal Policy Makers. Canada Mortgage and Housing Corporation. Retrieved from https://www03.cmhc- 
schl.gc.ca/catalog/productDetail.cfm?cat=123\&itm=73\&lang=en\&sid=ToSNfGN4ADXPPsC Xq6FSzEY7bwaOLfqSjpxg43Z1QVVFzp1ndAQS4fZ8eL1BWrOh\&fr=1522618530257

Lee, J. (2017). "Making Green Roofs Happen" in Toronto" Policy Analysis. Master of Planning Thesis; Queens University. Retrieved from https://qspace.library.queensu.ca/bitstream/handle/1974/22020/Lee_Joanne_201708_ MPL.pdf?sequence=1

Lehmann, S. (2014). Low Carbon Districts: Mitigating the Urban Heat Island with Green Roof Infrastructure. City, Culture and Society, 5, pg. 1-8.

Li, W. (2013) A Scenario Planning Approach for School Green Roofs to Achieve Stormwater Management Benefits: A Case Study of Brier's Mill Run Subwatershed. UMI Dissertation Publishing. Retrieved from https://drum.lib.umd.edu/bitstream/handle/1903/14188/Li_umd_0117N_14343.pdf;seq uence $=1$

Mees, H-L. P. \& Driessen, P. P. J. (2011). Adaptation to Climate Change in Urban Areas: Climategreening London, Rotterdam, and Toronto. Climate Law, 2, pp. 251-280.

Mendelsohn, R. (2000) Efficient adaptation to climate change, Climatic Change, 45(3-4), pp. 583-600.

Merk, O., Saussier, S., Staropoli, C., Slack, E., Kim, J-H. (2012). Financing Green Urban Infrastructure. OECD Regional Development Working Papers 2012/10, OECD Publishing; http://dc.doi.org/10.1787/5k92p0c6j6ro-en

Miller, N., Pogue, D., Gough, Q., Davis, S. (2009). Green buildings and productivity. Journal of Sustainable Real Estate 1(1), pp. 1-31.

Milton, D., Glencross, P., Walters, M. (2000). Risk of sick leave associated with outdoor air supply rate, humidification, and occupant complaints. Indoor Air, 10, pp. 212-221. 
Ministry of Education. (2016a, June 27). Ontario Investing \$1.1 Billion to Improve School Buildings: Province Supporting Better Buildings for Better Learning. Retrieved from https://news.ontario.ca/edu/en/2016/06/ontario-investing-11-billion-to-improve-schoolbuildings.html

Ministry of Education. (2017b, June 19). Capital Investments - Improving Ontario's Schools. Retrieved from http://www.edu.gov.on.ca/eng/parents/capital.html

Ministry of the Environment and Climate Change. (2017, August 30). Ontario Launches the Green Ontario Fund to Help People Save Money and Fight Climate Change. Retrieved from https://news.ontario.ca/ene/en/2017/08/ontario-launches-the-green-ontario-fundto-help-people-save-money-and-fight-climate-change.html

Ministry of the Environment and Climate Change. (2016a). Ontario's Climate Change Strategy. Retrieved from https://www.ontario.ca/page/climate-change-strategy

Ministry of the Environment and Climate Change. (2016b). Ontario's Climate Change Action Plan. Retrieved from https://www.ontario.ca/page/climate-change-action-plan

Ministry of the Environment and Climate Change. (2016c). Ontario Posts Cap and Trade Regulation: Province Reducing Greenhouse Gas Emissions, Creating Jobs. Retrieved from https://news.ontario.ca/ene/en/2016/02/ontario-posts-cap-and-trade-regulation.html

Ministry of the Environment and Climate Change. (2016d). Green Investment Fund. Retrieved from https://www.ontario.ca/page/green-investment-fund

Ministry of Finance. (2017). Ontario Budget: A Stronger, Healthier Ontario. Retrieved from https://www.fin.gov.on.ca/en/budget/ontariobudgets/2017/contents.html

Ministry of Municipal Affairs. (2015). City of Toronto Act, 2006. Retrieved from http://www.mah.gov.on.ca/Page343.aspx 
Ministry of Municipal Affairs. (2017a). Potential Changes to Ontario's Building Code: Summer and Fall 2017 Consultations. Retrieved from http://www.mah.gov.on.ca/AssetFactory.aspx?did=19609

Ministry of Municipal Affairs. (2017b). Growth Plan for the Greater Golden Horseshoe, 2017. Retrieved from http://placestogrow.ca/index.php?option=com_content\&task=view\&id=430\&Itemid=14

New York City Department of Education Office of Sustainability, School construction Authority, \& the Department of Environmental Protection Office of Green Infrastucture. (n.d). A Guide to Green Roofs on Existing School Buildings. Retrieved from http://schools.nyc.gov/NR/rdonlyres/F8102A3E-4958-49E3-A7F595ABD8646B3E/0/GreenRoofGuidance.pdf

Ngan, G. (2004). Green Roof Policies: Tools for Encouraging Sustainable Design. Retrieved from http://www.gnla.ca/assets/Policy\%20report.pdf

Norton, B. A., Coutts, A. M., Livesley, S. J., Harris, R., J., Hunter, A. M., \& Nicholas, S.G. Willaims. (2015). Planning for cooler cities: A framework to prioritize green infrastructure to mitigate high temperatures in urban landscapes. Landscape and Urban Planning, 134, pp. 127-138.

Peck, S. W., \& Kuhn, M. (n.d). Design Guidelines for Green Roofs. Retrieved form http://aanb.org/wp-content/uploads/2016/08/Design-Guidelines-for-Green-Roofs-1.pdf

Peck, S.W., C. Callaghan, M. Kuhn, and B. Bass. 1999. Greenbacks from green roofs: Forging a new industry in Canada. Canada Mortgage and Housing Corporation. Ottawa, Canada.

Peck, S. W. (2001). Green Roofs: Infrastructure for the $21^{\text {st }}$ Century Exploiting the Last Urban Frontier. Retrieved from http://rci-online.org/wp-content/uploads/2001-11-peck.pdf

Research and Information Team in Strategic Initiatives, Policy and Analysis Division, City Planning, City of Toronto. (2017). Land Use Information II: Site Plan Applications, relating to Public School sites, between January 1st 2010 and October 27th, 2017, City of Toronto. 
Retrieved from Shayna Stott, City Planning Strategic Initiatives, Policy and Analysis Division.

Rider, D. (2017, May 16). Toronto Flushes Plan for Stormwater Fee: Mayor John Tory helps shelve proposal for a dedicated fee to fund stormwater management. TorontoStar. Retrieved from https://www.thestar.com/news/city_hall/2017/05/16/toronto-flushesplan-for-stormwater-fee.html

Roberts, W. (2012, May 3). Hitting the Green Roof: Crucial vote will decide if City is serious about its green roof policy. Now Toronto. Retrieved from https://nowtoronto.com/news/hitting-the-green-roof/

Rushowy, K. (2016, June 27). Province Pledges \$1.1 Billion Boost for School Repairs: Money to fix roofs, boilers, windows to address backlog, pegged as high as \$15 billion across Ontario. Toronto Star. Retrieved from https://www.thestar.com/yourtoronto/education/2016/06/27/province-pledges-11billion-boost-for-school-repairs.html

Sproul, J., Wan, M. P., Manel, B. H., \& Rosenfeld, A. H. (2014). Economic Comparison of white, green, and black flat roofs in the United States. Energy and Buildings 71, 20-27.

Toronto Building Plan Review Section. (2018). Building Permits - Green Roofs. [Data file]. Retrieved from https://www.toronto.ca/city-government/data-research-maps/opendata/open-data-catalogue/\#567e786d-8e5d-5a59-1b98-7032905fabaa

Toronto City-School Boards Advisory Committee. (2016, June 24). Toronto Green Development Requirements and Green Roof By-law. Retrieved from http://app.toronto.ca/tmmis/viewAgendaltemHistory.do?item=2016.TS4.4

United States Environmental Protection Agency. (2017). Using Green Roofs to Reduce Heat Islands. Retrieved from https://www.epa.gov/heat-islands/using-green-roofs-reduceheat-islands 
Vijayaraghavan, K. (2016). Green Roofs: A Critical Review on the role of Components, Benefits, Limitations and Trends. Renewable and Sustainable Energy Reviews, 57, 740-752.

Weekes, J. M. (2009). Green Schools: Strengthening our Economy by Investing in our Children. New Solutions, 19(2), pp. 255-257.

William, R., Goodwell, A., Richardson, M., Le, P. V. V., Kumar, P. \& Stillwell A. S. (2016). An Environmental Cost-Benefit Analysis Of Alternative Green Roofing Strategies. Ecological Engineering, 95, page 1-9.

Zinzi, M. \& Agnoli, S. (2012). Cool And Green Roofs. An Energy And Comfort Comparison Between Passive Cooling and Mitigation Urban Heat Island Techniques for Residential Buildings in The Mediterranean Region. Energy and Buildings, 55, pp. 66-76. 